\title{
Lateglacial-Holocene shoreface progradation offshore Eastern Scotland: a response to climatic and coastal hydrographic change
}

Stoker, M.S., Golledge, N.R., Phillips, E.R., Wilkinson, I.P. and Akhurst, M.C:

Lateglacial-Holocene shoreface progradation offshore Eastern Scotland: a response to climatic and coastal hydrographic change

Seismic facies, provenance and marine faunal associations of a nearshore prograding sediment wedge offshore eastern Scotland are studied to investigate environmental changes in the adjacent North Sea during Lateglacial-Holocene time. The sediments form part of the St Andrews Bay Member (Forth Formation), which is divided into four lithozones (L1-L4) that represent distinct pulses of sedimentation during the sequential growth of the sediment wedge. Radiocarbon dates combined with the local curve of relative sea level change indicate that progradation was initiated as a fluvio-deltaic deposit (L1) during the Younger Dryas Stadial. Further construction of the sediment package took place during the mid- to late Holocene by sub-littoral tidal processes that deposited three discrete, highstand shoreface wedges (L2-L4), which display both progradation and longshore migration (to the $\mathrm{NE}$ ), and may have experienced episodic brackish marine conditions. A depositional cyclicity of about 1000 years is proposed for lithozones L2-L4, separated by hiatuses of 1000-2000 years. We tentatively suggest that the Holocene development of the prograding wedge offshore eastern Scotland was a response to phases of strong westerly winds driving an enhanced influx of Atlantic water into the North Sea. A concomitant increase in rainfall may account for the freshening of the coastal zone at this time. However, correlation with the recently postulated global periods of Holocene rapid climate change remains unclear. 
Keywords: North Sea; Younger Dryas; Lowstand; Highstand; North Atlantic Drift Current Martyn Stoker, [e-mail: mss@bgs.ac.uk],Nick Golledge, [e-mail: nrgo@bgs.ac.uk],Emrys Phillips,[e-mail: erp@bgs.ac.uk],Maxine Akhurst,[e-mail: mcak@bgs.ac.uk],British Geological Survey, Murchison House, West Mains Road, Edinburgh, EH9 3LA, Scotland, UK; Ian Wilkinson, [e-mail: ipw@bgs.ac.uk],British Geological Survey, Kingsley Dunham Centre, Keyworth, Nottingham, NG12 5GG, England, UK.

The transient nature of the coastline is nowhere more pronounced than on the margins of former ice sheets, where landscape development, both terrestrial and marine, is highly sensitive to the interplay between glacio-isostatic and eustatic change following deglaciation. In eastern Scotland, the demise of the last British Ice Sheet - the Main Late Devensian (Weichselian) Stadial (Bradwell et al. 2008) - has left a terrestrial record of Late Devensianearly Holocene shoreline displacement that has been well documented for over forty years (Sissons et al. 1966; Sissons 1976; Cullingford 1977; Cullingford \& Smith 1980; Paterson et al. 1981). Fluctuations in relative sea level during this interval are generally recorded as a series of raised, highstand, shorelines and associated estuarine and marine sequences that are preserved in the coastal belt extending from the Firth of Forth northeastward to Stonehaven and beyond (Fig. 1). In contrast, little attention has been paid to the equivalent marine coastal record for which there is some indication for submerged, lowstand, rock platforms and fluviodeltaic deposits (Sissons 1974; Stoker et al. 1985), which do not feature in published curves of Lateglacial-Holocene change in relative sea level (cf. Hansom \& McGlashan 2004 and references therein). Consequently, without considering the marine component of coastal 
landscape change, current understanding of Lateglacial-early Holocene coastal development is likely to remain both unbalanced and incomplete.

Connectivity across the coastal zone, since the early Holocene, is even less well documented. As with much of the North Sea region, the early mid-Holocene record of onshore eastern Scotland (about 8000 to $6000{ }^{14} \mathrm{C}$ yr BP: Mangerud et al. 1974) is initially one of eustatic sea-level rise and coastal inundation, whereas marine regression down to present-day sea level has occurred in this area since the late mid-Holocene. A dynamic sedimentary environment has been proposed in the adjacent North Sea since about $6000{ }^{14} \mathrm{C}$ $\mathrm{yr} \mathrm{BP}$ on the basis of bedform development, such as sand ribbons and sand waves, and the coarse-grained nature of the sea bed sediments (Owens 1981). Whether or not these bedforms are currently active is unclear; however, the main source of modern-day longshore sand transport in nearshore areas such as St Andrews Bay and the Firth of Tay (Fig. 1) is envisaged to be the reworking of unconsolidated offshore Lateglacial-Holocene sediment (Ferentinos \& McManus 1981; Hansom 1999). By way of contrast, most of the fluviatile input to the coastal zone is presently trapped within the estuaries of the Forth and Tay (Gatliff et al. 1994).

In this paper, we present the results of investigations in the coastal area offshore eastern Scotland (Fig. 1), including insights into Lateglacial base level and Holocene shoreface sediment dynamics. It has recently been suggested that climate variability during the Holocene is characterised by as many as six distinct periods of rapid climate change (ranging from 200 to 1000 years duration), which may be correlated globally (Mayewski et al. 2004). In the North Atlantic region, this variability includes fluctuations in the strength of westerly winds. On this basis, we test the possible significance of these periods of rapid climate change using the pattern of coastal sedimentation that we observe in the western 
North Sea. In particular, the observed cyclicity in sediment deposition is compared with changes in North Atlantic current strength and periods of increased rainfall, which are intrinsically linked to a strong westerly circulation.

\section{Regional setting}

The study area consists of a 15 to $30 \mathrm{~km}$-wide coastal strip that extends from Fife Ness in the SW to Inverbervie in the NE (Fig. 1). Over most of this area the sea bed is relatively smooth and marked by coast-parallel contours that indicate a gentle seaward gradient $\left(0.15-0.2^{\circ}\right)$ down to about $50 \mathrm{~m}$ below ordnance datum (OD). To the east of this zone, the sea bed displays a more varied topography that consists of shallow marine banks ( $\leq-50 \mathrm{~m} \mathrm{OD}$, e.g. Marr Bank) interspersed with deeper (up to $-90 \mathrm{~m}$ OD) erosional troughs. The irregular physiography represents a relict ice-contact/ice-marginal landsystem associated with the Main Late Devensian (Weichselian) Strathmore ice stream (Golledge \& Stoker 2006); morainic ridges of the Wee Bankie Formation (Fig. 2) comprise the shallow banks whereas the erosional troughs are part of a contemporaneous tunnel valley system. The Wee Bankie Formation is partially buried beneath a drape of shallow-water glacimarine (St Abbs Formation) and marine (Largo Bay Member of the Forth Formation) sediments, which were deposited as relative sea level fell during deglaciation. All of these units are overlain by a discrete sediment wedge that shapes the smoother coastal zone (Figs 3, 4). This sediment wedge is defined as the St Andrews Bay Member of the Lateglacial-Holocene Forth Formation (Stoker et al. 1985) (Fig. 2), and forms the focus of this paper.

The St Andrews Bay Member is mapped for a distance of about $70 \mathrm{~km}$ between Fife Ness and Inverbervie (Fig. 1), and extending 10 to $20 \mathrm{~km}$ offshore. The unit occurs within a 
present-day water depth range of 20 to $60 \mathrm{~m}$ below OD, with the shallow top of the unit (where observed) currently between about 25 and $40 \mathrm{~m}$ below OD. Regional seismicstratigraphic mapping indicates that it forms a wedge-shaped deposit that locally exceeds 10 $\mathrm{m}$ thick (Figs 3, 4, 5), with the thickest part of the wedge (up to $17 \mathrm{~m}$ thick) extending seaward of the $30 \mathrm{~m}$ bathymetric contour. The landward extent of the unit remains unclear, lying beyond the western limit of the dataset (Fig. 1). The sediment wedge progrades seaward, but is also elongated parallel to the coastline. The upper boundary of the St Andrews Bay Member is the present-day sea bed; its base is a downlap surface predominantly underlain by Late Devensian till, glacimarine and marine sediment (Figs 4, 5).

On deep-tow boomer profiles, the internal acoustic reflection configuration of the $\mathrm{St}$ Andrews Bay Member is characterised by seaward-prograding, low-angle $\left(<1.5^{\circ}\right)$ clinoforms, which vary from oblique-parallel to sigmoid in geometry (Fig. 5). The topset zone is very thin and largely an area of erosion (Figs 4, 5). A consistent variation in clinoform geometry and seismic facies has enabled the subdivision of the St Andrews Bay Member into four informal units (Figs 2, 4, 5, 6). On the basis of lithological and compositional data from the various cores that penetrate the sediment wedge, these units are herein referred to as lithozones (Salvador 1994), which is consistent with the general lithostratigraphic hierarchy established for the Quaternary of the UK central North Sea (Stoker et al. 1985). The lithozones are assigned as L1 to L4 in ascending stratigraphic order (Fig. 2).

The geomorphology of the eastern Scottish coastal region records a legacy of the Lateglacial to early Postglacial interplay between isostatic rebound and the eustatic rise in sea level associated with deglaciation. This legacy is manifested in a series of displaced shorelines that are currently preserved both above and below present-day sea level. The 
highest raised shorelines are located at altitudes of up to +30 to $+40 \mathrm{~m}$ above OD (Paterson et al. 1981), and developed as the land began to recover from glacio-isostatic depression between about 15100 and $13500{ }^{14} \mathrm{C}$ yr BP (Andrews \& Dugdale 1970; Paterson 1974). At maximum regression, large amounts of glaciofluvial sand and gravel prograded into the area of the Firth of Tay estuary (Fig. 1), and the elevation of the relative sea level minimum fell below present OD in the Firth of Tay and Firth of Forth estuaries. In both estuaries, a buried shelly gravel layer (including the Port Allen Gravel: Fig. 5) overlies a submerged rock platform presently located between OD and-10 m OD (Sissons 1974; Paterson et al. 1981). This platform is generally regarded as the Main Lateglacial Shoreline and is considered to have formed during the Younger Dryas Stadial (Sissons, 1974), possibly at about $10800{ }^{14} \mathrm{C}$ yr BP (Paterson et al. 1981).

The rate of land uplift in eastern Scotland remained greater than the rate of rise of global sea level until about $8400{ }^{14} \mathrm{C}$ yr BP (Jardine 1979) when, in common with much of the North Sea region, the rate of global eustacy overtook terrestrial rebound (Behre 2007). A prominent shoreline, the Main Postglacial Shoreline (up to +9 m OD), was formed at the maximum of the postglacial transgression in eastern Scotland, which had probably ceased by about $6000{ }^{14} \mathrm{C}$ yr BP (Paterson et al. 1981). Marine regression has largely dominated eastern Scotland since the late mid-Holocene.

Palaeogeographic reconstruction of NW Europe (Shennan et al. 2000) indicates that the study area has been part of a tidally-influenced marine basin since the Lateglacial Interstadial, concomitant with the initial penetration of warmer Atlantic currents into the Norwegian Trench and the northern and central North Sea (Thomson 1978; Lehman et al. 1991; Lehman \& Keigwin 1992; Veum et al. 1992; Koç et al. 1993; Brew 1996; Knudsen et 
al. 1996). Initially part of a restricted basin that incorporated the area of the Norwegian Trench and a western embayment located between the Dogger Bank and eastern Scotland/NE England (Fig. 1B), it gradually expanded to the present-day North Sea as sea level rose. As a consequence, the most significant changes in palaeogeography have occurred in the shallower eastern and southern North Sea, including: 1) the connection between the North Sea and the English Channel between about 9000 and 7000 cal. yr (c. 8300 to $6000{ }^{14} \mathrm{C}$ yr BP), though a fully marine environment may have existed only since $6000 \mathrm{cal}$. yr (c. $5400{ }^{14} \mathrm{C}$ yr BP) (Eisma et al. 1981; Lambeck 1995; Behre 2007); and, 2) the isolation at about 7000 cal. yr (c. $6000{ }^{14} \mathrm{C}$ yr BP) and eventual submergence of the Dogger Bank (Fig. 1B) between 6000 and 5000 cal. yr (c. 5400 to $4500{ }^{14} \mathrm{C}$ yr BP ) (Shennan et al. 2000; Behre 2007). Concomitant with these changes was the development of the modern circulation pattern in the North Sea, which is mainly driven by the inflow of Atlantic waters (North Atlantic Drift Current; Fair Isle Current) between Scotland and Norway (Longva \& Thorsnes 1997; Hebbeln et al. 2006) (Fig. 1B). This inflow stimulates a counter-clockwise circulation in the North Sea, with part of the water mass following depth contours in the northern North Sea, whereas other parts flow around the entire basin where its properties are modified by freshwater input from numerous large rivers (e.g. Thames, Rhine) as well as mixing with Channel Water. The outflows combine in the Skagerrak (between Denmark and Norway), further incorporating Baltic outflow, to form the northward flowing Norwegian Coastal Current. Offshore eastern Scotland, the coastal zone is bathed by southerly flowing Scottish Coastal Water, which is part of the basinwide system of coast-parallel currents (Harland \& Long 1996; Evans et al. 2002; Gyllencreutz et al. 2006). Harland \& Long (1996) report the existence of Scottish Coastal Water off NE England from about $8000{ }^{14} \mathrm{C}$ yr BP. 
This oceanographic pattern is strongly influenced by atmospheric circulation, with strong westerly winds enhancing the currents whereas easterly winds dampen the currents (Hebbeln et al. 2006). As much of the North Sea is shallow $(<100 \mathrm{~m})$ it is characterised by high tidal- and wave-energy levels, with the tidal stream aligned parallel to the coastline (Pantin 1991; Gatliff et al. 1994). Mean spring tidal near-bottom current velocities together with storm-wave induced currents have the capacity to erode sediments from medium sand grade to gravel grade (Owens 1981; Pantin 1991). It has been demonstrated that shoreface reworking in response to tide- and wave-induced currents is an important element of the Holocene sediment dynamic regime along the western North Sea coastline (Ferentinos \& McManus 1981; Shennan et al. 2003). Offshore eastern Scotland, the observed pattern of sand and gravel sea floor bedforms implies a predominantly northerly sediment transport path (Kenyon \& Stride 1970; Stride 1973; Owens 1981) (Fig. 1B). This is consistent with the strongest tidal flow being associated with the ebb tidal current (Kenyon \& Stride 1970; Lee \& Ramster 1981).

\section{Methods and material}

This study combines high-resolution seismic reflection data with core information collected by the British Geological Survey (BGS) as part of their offshore reconnaissance Quaternary mapping programme. The seismic reflection data was acquired using a high-frequency $6 \mathrm{kV}$ deep-tow boomer source, which has a sub-sea bed penetration of up to $100 \mathrm{~m}$ and a vertical resolution of $0.25-1.0 \mathrm{~m}$. Interpretation of the data was based on established concepts of seismic reflection, facies and attribute analysis as defined by Mitchum et al. (1977) and Sangree \& Widmier (1977). Conversion of two-way travel time to metres is based on an acoustic velocity of $1500 \mathrm{~ms}^{-1}$. Geological calibration of the seismic data utilised information 
from three cores: BGS vibrocores 56-03/586 and 587, and BGS borehole 74/15 (Figs 1, 2;

Table 1). These cores have been analysed in terms of their lithology, sedimentary structure, composition and microfaunal content. The macrofauna of a distinctive shell hash in core 5603/587 was also examined. Material from all three cores was submitted for radiocarbon dating.

Graphic logs of the cores were produced from macro- and microscopic examination of the sediments (Fig. 6). For the latter, twenty two samples were analysed for their petrography and composition. The samples were prepared as grain mount thin sections and examined using a standard Zeiss petrological microscope. The petrography of these sediments is presented in Table 2. Modal compositional data were calculated, from point counting of grain mounts, as volumetric proportions of categories of detrital grains as recommended by Dickinson \& Suczek (1979). Counts per sample are listed in Table 3 and plotted graphically on Figs 7, 8, 9, and include the following categories of detrital grains (after Dickinson \& Suczek 1979): stable quartz grains (Q) including both mono- (Qm) and polycrystalline (Qp) quartz; monocrystalline feldspar (F) grains including plagioclase ( $\mathrm{Pl}$ ) and K-feldspar (Ksp); unstable polycrystalline lithic fragments (L) of three main types, namely volcanic (Lv), metamorphic (Lm) and sedimentary (Ls) rock fragments. The total lithic component (Ltotal) of the sediments represents the sum of the unstable lithic fragments (L) plus stable polycrystalline quartz (Qp) grains. The key aspects of the petrographic and compositional data are summarised in Table 4.

Sixteen samples were analysed for their foraminiferal and ostracod content (Tables 5, 6), with specimens picked from dry residues ( $>72 \mathrm{mg})$. Up to a maximum of 300 specimens 
were counted for the foraminifera. In contrast, the whole population of ostracods was identified as the counts were much less than 300 specimens.

Well-preserved, non-abraded, marine shells and benthic foraminifera were used to obtain accelerator mass spectrometry (AMS) radiocarbon ages (Table 7). Whole single valves of Arctica islandica and Macoma calcarea were recovered from core 56-03/587, whereas the benthic foramimifera Ammonia batavus was sampled from core 56-03/586 and borehole 74/15. A minimum of $20 \mathrm{mg}$ of foraminifer was picked out for each sample. All of these samples were subsequently prepared for dating at the Natural Environment Research Council Radiocarbon Laboratory at East Kilbride, UK. All offshore ${ }^{14} \mathrm{C}$ dates reported here are corrected with a marine reservoir age of $405 \pm 40 \mathrm{yr}$ (Harkness 1983). As most of the previously published dates specific to the study area are given in ${ }^{14} \mathrm{C} \mathrm{yr} \mathrm{BP}$, this standard is retained for direct comparison between onshore and offshore data. However, for correlation of our data to global events (see Discussion), our new radiocarbon ages have been calibrated to calendar years (Table 7) based on the Fairbanks0107 calibration curve (Fairbanks et al. 2005). The chronostratigraphic subdivision of the Holocene is based on Mangerud et al. (1974).

\section{Results}

The seismic, lithological and palaeontological characteristics of lithozones L1, L3 and L4 are summarised below; in the absence of any core material for L2, it is described only in terms of its seismic facies. The radiocarbon chronological data are presented at the end of the section.

\section{Lithozone 1}


Seismic character. - This unit is up to $9 \mathrm{~m}$ thick and is acoustically well layered, with an internal oblique-parallel (sensu Mitchum et al. 1977) reflection configuration. Downlapping clinoforms dip seaward at angles of up to $1.0-1.2^{\circ}$. The upper bounding surface is everywhere erosional, and presently lies at about $30 \mathrm{~m}$ below sea level. The youngest clinoforms are truncated and locally scoured at the contact with L2. The topset zone is nowhere preserved, and an erosional unconformity separates L1 from the overlying sediment veneer (most probably L4) (Figs 4, 5). The seaward limit of L1 is shown in Fig. 3B.

Lithology. - A 0.7 m-thick section of L1 was sampled in core 56-03/587, between 1.38 and $2.08 \mathrm{~m}$ below sea bed (Fig. 6). This consists of dark greyish brown (2.5Y 4/2) (Munsell colour code), upward-fining, medium to very fine-grained sand and coarse silt. The sediment is composed predominantly of quartz, lithic fragments and plagioclase with subordinate minor and accessory minerals (Figs 7, 8A; Tables 2, 3, 4). Bioclastic material is rare (see below) (Figs 7D, 8A; Table 3). The upward-fining texture represents a distribution grading. The contact with the overlying lithozone, L4, is marked by a sharp erosional surface.

Palaeontology. - Foraminifera are extremely rare with only a few specimens of Elphidium excavatum clavatum, Buccella frigida, Cibicides lobatulus, Elphidium incertum and Quinquloculina seminulum recorded in core 56-03/587 (Table 5). Similarly, L1 was almost devoid of ostracods, with only a single recovered species of Cytheropteron nodosum (Table 6). A large single valve of the bivalve Macoma calcarea was sampled near the base of core $56-03 / 587$.

\section{Lithozone 2}


Seismic character. - This unit is up to $7 \mathrm{~m}$ thick and is acoustically well layered, with an internal sigmoid-oblique tangential reflection configuration (Figs 4, 5). Downlapping clinoforms commonly dip seaward at angles of $0.25-0.5^{\circ}$, though an angle of about $1.1^{\circ}$ is observed on boomer profile $80-03 / 14$ (Fig. 5). The lower boundary is an erosional contact that not only truncates clinoforms within the underlying L1 lithozone, but also erodes into the St Abbs Formation (Figs 4, 5). The upper boundary is largely conformable with L3 in the clinoform zone, though there is a hint of erosional truncation at the distal edge of the unit. The topset zone has been largely removed by later erosion. The seaward limit of L2 is shown in Fig. 3B.

\section{Lithozone 3}

Seismic character. - This unit is up to $10 \mathrm{~m}$ thick and is mainly acoustically structureless and opaque, though weak oblique tangential reflections are sporadically observed (Figs 4, 5). Clinoforms commonly dip seaward at angles of $0.25-0.5^{\circ}$. A flat-lying bottomset zone is locally preserved (Fig. 5). The lower boundary is predominantly conformable with the underlying L2 lithozone, though localised erosion is observed. The upper boundary appears to be largely conformable with L4 in the clinoform zone, but on boomer profile 80-03/14 the upper bottomset surface forms a downlap surface for L4 (Fig. 5). The topset zone has been largely removed by later erosion. The seaward limit of L3 is shown in Fig. 3B.

Lithology. - The distal end of L3 was sampled between 3.5 and $5.5 \mathrm{~m}$ below sea bed in borehole $74 / 15$, although sample recovery was poor. The borehole proved a $2.0 \mathrm{~m}$-thick section of dark olive grey (5Y 3/2), very fine-grained micaceous sand to coarse silt (Fig. 6), composed predominantly of quartz, plagioclase and mica (combined biotite and muscovite), 
with subordinate lithic fragments and accessory minerals (Figs 7, 8B; Tables 2, 3, 4). The bioclastic content is low (see below) (Figs 7D, 8B). The poor sample recovery precludes any observation on the sedimentary structure of L3, though the grain size and composition are fairly uniform throughout the lithozone. In borehole 74/15, L3 rests with angular unconformity on dark greyish brown (10YR 4/2) glacimarine clay of the underlying St Abbs Formation; the nature of the upper contact with L4 was not observed in the borehole.

Palaeontology. - The foraminiferal assemblage is low in content and in diversity (Table 5). The preserved assemblage is dominated by Ammonia batavus and E. excavatum, clavatum with rare specimens including C. lobatulus, E. incertum and Bulimina marginata. A single specimen of Bulimina elongata was observed in sample MPA55505 in the upper part of the unit. The ostracod content of L3 is restricted to a single specimen of Elofsonella concinna recovered from the base of the unit (Table 6). A single specimen of the gastropod Turritella communis was observed near the base of the core.

\section{Lithozone 4}

Seismic character. - This unit is up to $8 \mathrm{~m}$ thick and is acoustically layered, with an internal sigmoid-oblique reflection configuration (Figs 4, 5). Downlapping clinoforms commonly dip seaward at angles of $0.25-0.5^{\circ}$. The lower boundary is predominantly conformable with the underlying L3 lithozone, though downlap onto L3 bottomsets is locally developed. The upper boundary is the sea bed. A thin $(<2 \mathrm{~m}$ thick) topset zone is preserved and extends landward from about $35 \mathrm{~m}$ to $25 \mathrm{~m}$ (at the landward end of the seismic profiles) below OD. The base of the topset zone has eroded into the underlying L1 to L3 lithozones. The seaward limit of L4 is shown in Fig. 3B. 
Lithology. - Lithozone L4 has been sampled in all three cores in this study: from sea bed to $5.9 \mathrm{~m}$ in core $56-03 / 586$; from sea bed to $1.38 \mathrm{~m}$ in core $56-03 / 587$; and from sea bed to $3.5 \mathrm{~m}$ in borehole 74/15 (Figs 2, 6). Core 56-03/586 and borehole 74/15 tested the clinoform facies, whereas core $56-03 / 587$ penetrated the topset facies.

The clinoform facies consists of dark greyish brown (2.5Y 3/2-10YR 4/2), moderately sorted, coarse silt to very fine-grained sand, which is composed predominantly of quartz, plagioclase and lithic fragments, with subordinate mica (combined biotite and muscovite) and other accessory minerals (Figs 7, 8D-E, 9B; Tables 2, 3, 4). Bioclastic material occurs throughout this facies, with sporadic discrete laminations $(<1 \mathrm{~cm}$ thick $)$ rich in shell fragments. In borehole $74 / 15$, the poor sample recovery precludes any observation of sedimentary structure in L4; however, in core 56-03/586 crude decimetre- to metre-scale bedding is interpreted on the basis of observed grain size variation within the section, and reveals an alternation between beds of coarse silt and very fine-grained sand (Fig. 6). The nature of the contact between the beds is not preserved but is inferred to be sharp, on the basis of the distinct bimodal grain size.

The topset facies is represented in core 56-03/587 by an upwards-fining sequence of sand that overlies a sharp and erosive base cut into the underlying L1 lithozone (Fig. 6). The base of the upwards-fining sequence is marked by a $0.15 \mathrm{~m}$-thick shell hash that overlies the unconformity, and consists of both fragmented and whole bivalve shells, gastropod shells and worm tubes (see below), which are aligned subhorizontal defining a planar parallel lamination. The shell material is set within a matrix of very dark grey (5Y 3/1), medium to fine, moderately sorted sand that grades upwards into very fine-grained sand to coarse silt 
grade material at the top of the core. The sand is composed predominantly of quartz with common lithic fragments and plagioclase, with subordinate mica and accessory minerals (Figs 7, 8C; Tables $2,3,4)$. Bioclastic material occurs throughout this facies (see below), though there is an increase in content below $0.65 \mathrm{~m}$ depth.

Palaeontology. - Foraminifera were recovered from all three cores, though core 56-03/586 records the greatest variation. In this core, diversity is low at the base $(5.8 \mathrm{~m})$ but increases up the core (Table 5). A. batavus is dominant throughout the section, commonly occurring in flood proportions ( $>75 \%$ of the total assemblage). Rare B. marginata is found up to a depth of $4.0 \mathrm{~m}$, where it is replaced by B. elongata. Specimens of Eggerelloides scaber and Haynesina anglica are rare to frequent at $2.6 \mathrm{~m}$ and above. Comparable faunas are also recorded in core 56-03/587 and borehole 74/15 (Table 5). The sporadic occurrence of species such as $E$. excavatum clavatum, Elphidium bartletti and Haynesina orbiculare in all three cores may be indicative of reworking from the glacigenic St Abbs or Wee Bankie formations, which are dominated by these taxa (cf. Gregory et al. in Thomson 1978).

Lithozone L4 also has the largest assemblage of ostracods, though diversity remains low, and none of the assemblages are especially rich (Table 6). As with the foraminifera, core 56-03/586 records an upwards increase in diversity with E. concinna, Robertsonites tuberculatus, Pterygocythereis jonesii and Palmoconcha guttata being most common. The fauna in core $56-03 / 587$ and borehole $74 / 15$ is more patchy, but essentially similar, and also includes Hirschmannia viridis and Leptocythere psammophila. Rare specimens of Arctic species such as Finmarchinella angulata, , Rabimilis mirabilis, Hemicytherura clathrata, in borehole 74/15 are probably reworked. 
A diverse macrofaunal assemblage was recovered from the shell hash in core 5603/587, between 1.3 and $1.35 \mathrm{~m}$, which includes the serpulid polychaete Ditrupa arietina, together with abundant gastropods and molluscs. The gastropods include Acteon tornatalis, Cingula semicostata, Cylichna cylindracea, Oenopota turricula, Retusa obtusa and T. comunis. The mollusc assemblage consists of Abra nitida, Acanthocardia echinata, Arctica islandica, Chlamys opercularis, Nucula cf. nucleus, and Venus casina.

\section{Radiocarbon dating}

A total of six samples (bivalve molluscs and benthic foraminifera) have been $\mathrm{AMS}{ }^{14} \mathrm{C}$ dated from lithozones 1, 3 and 4 (Fig. 6, Table 7). The dates indicate that the cored sequence roughly spans the last $10500{ }^{14} \mathrm{C}$ yr BP (ca. 12500 cal. yr). Although the seismic and lithofacies character of the lithozones indicates some degree of reworking, which implies that the dates are maximum ages, the well preserved and non-abraded nature of the sample specimens together with their sequential increase in age down-sequence suggests that any reworking was largely penecontemporaneous with deposition. Thus, we regard the chronology to be a reasonable indicator of the time of deposition.

In core 56-03/587, an age of $10543 \pm 55{ }^{14} \mathrm{C}$ yr BP was determined from the $M$. calcarea valve from a depth of $2.0 \mathrm{~m}$ in lithozone L1. In lithozone L3, ages of $4959 \pm 54$ and $4944 \pm 53{ }^{14} \mathrm{C}$ yr BP were determined from A. batavus in borehole 74/15, at a depth of $5.5 \mathrm{~m}$ and from the interval 3.5-5.0 m, respectively. For lithozone L4, ages of $2224 \pm 54$ and $2219 \pm 54{ }^{14} \mathrm{C}$ yr BP were determined from A. batavus in core 56-03/586, at depths of $2.55-$ $2.65 \mathrm{~m}$ and $2.27-2.4 \mathrm{~m}$ respectively, whereas in core $56-03 / 587$, an age of $1377 \pm 53{ }^{14} \mathrm{C}$ yr BP was determined from an A. islandica valve from the shell hash at the base of the core. 


\section{Interpretation}

The main characteristics and interpretation of the deposits of the four lithozones are summarised in Table 8; the interpretation of L2 is based on a comparison with L3 and L4. From a cursory inspection of the geophysical profiles (Figs 4, 5), it might be inferred that the St Andrews Bay Member represents a single, composite, prograding lowstand wedge (e.g. Stoker et al. 1985; Stoker 1987); however, this study reveals significant differences between L1 and the overlying lithozones. Moreover, the stratigraphic range of the St Andrews Bay Member (Younger Dryas to Late Holocene) implied by the radiocarbon dating is far more extensive than previously reported (Stoker et al. 1985). When correlated to the local sea level curve (Fig. 10), this has major implications for the interpretation of the depositional setting of the lithozones (see below).

The contrast between L1 and L2-4 is demonstrated below through reference to their seismic facies, petrography and sand composition, and microfaunal assemblage. Collectively, these attributes form the basis for the interpretation of depositional environments.

Seismic facies

Seismic facies analysis indicates a switch from an oblique-parallel clinoform profile in L1 to a predominantly sigmoid-oblique clinoform profile in L2 to L4, which define a more concaveupward stratal configuration (Figs 4, 5). An oblique progradational reflection pattern is generally interpreted to represent a relatively high-energy sedimentary regime, characterised by some combination of relatively high sediment supply, slow to no basin subsidence, and a 
stillstand of sea level that enables sediment bypass or scour of the upper depositional surface (Mitchum et al. 1977). Although all lithozones display an oblique clinoform profile to some degree, the depositional dip in L1, albeit low, is twice that of L2 to L4. A shallower depositional dip and sigmoid clinoform profile may imply a lower energy regime for L2 to L4; however, the similarity in lithology between L1, L3 and L4 might suggest that the energy differential was not large. This is significant given that the AMS ${ }^{14} \mathrm{C}$ radiocarbon dates combined with the sea-level curve indicate that L1 was deposited during a lowstand associated with the Younger Dryas Stadial, whereas L3 and L4 (and most probably L2) were laid down during the mid- to late Holocene highstand (Fig. 10). The present confinement of a thin topset zone to L4 supports the concept that a high-energy erosional regime has persisted adjacent to the coastline since the Younger Dryas Stadial albeit responding to two very different depositional mechanisms, as is discussed further below.

\section{Petrography and sand composition}

Petrographic observation and modal compositional data show that there are significant differences between the sediments of L1 and those of L3 and L4 (Tables 2, 3, 4). In general, the sediment in L1 is coarser grained and more lithic-rich than the sediments from L3 and L4. The medium- to fine-grained sand in L1 is clearly discriminated by its higher polycrystalline quartz (Fig. 7A), volcanic (Fig. 7B) and metamorphic (Fig. 7C) lithic clast components, and lower bioclastic (Fig. 7D) and mica (biotite and muscovite, Fig. 7E, F, respectively) content. The higher monocrystalline quartz, biotite and muscovite contents exhibited by the finegrained sands and coarse silts of L3 and L4 are consistent with an increasing textural maturity of the sediment (trend lines on Fig. 7A, C) with time and concentration of detrital phyllosilicate minerals within the finer grained silty sediments. 
The compositional differences between the lithozones are further evident when the data are plotted as a series of multicomponent variation diagrams (Fig. 8). The sands of L1 possess detrital phyllosilicate (biotite, muscovite, chlorite) and heavy mineral (garnet, opaque minerals, amphibole, epidote) contents of close to or below 1\% (Fig. 8A). In contrast, the more micaceous sediments of L3 are distinguished by the slightly 'humped' section of the pattern corresponding to the detrital phyllosilicate minerals (Fig. 8B). Although the fine sands and coarse silts of L4 show some compositional differences between the cores that penetrated this lithozone (see Fig. 7) they exhibit a very similar pattern on Fig. 8. This suggests that variations within L4 probably reflect the variation in grain size and, therefore, a change from a more proximal (56-03/587) to distal (56-03/586 and 74/15) depositional environment.

The sands of L1 contain a significant metamorphic component (rock fragments, garnet, staurolite, chloritoid) indicating that the source terrane included the metamorphic rocks of the Dalradian Southern Highland Group, which are exposed to the north and west of Stonehaven (Fig. 1). Altered, very fine-grained volcanic rock fragments are inferred to be derived from the Late Silurian to Early Devonian volcanic rocks (e.g. Montrose Volcanic Formation) which crop out in the Montrose area (Fig. 1). These components (albeit reduced percentage) are also recognised as heavy minerals in L3 and L4 (Fig. 7B, C, Tables 2, 3), where their occurrence suggests that either the same provenance was being sourced, or that the sands of L1 were being reworked. Evidence for some reworking of L1 during the deposition of L4 is provided by Fig. 9A. The slightly coarser-grained sand at the base of L4 is compositionally similar to the underlying sand. The upwards (stratigraphically) increase in monocrystalline quartz, biotite and muscovite, and concomitant decrease in the more unstable detrital components (such as polycrystalline quartz and metamorphic lithic clasts) are 
consistent with the increasing maturity of the sediment and overall decrease in grain size of the sediments within this fining upwards sequence. Similar stratigraphical variations in sediment composition can also be identified within L4 (Fig. 9B) indicating that the reworking also occurred during the deposition of a single lithozone.

\section{Microfaunal assemblages}

Late Pleistocene and Holocene benthic foraminifera and ostracods are present throughout lithozones L1, L3 and L4 of the St Andrews Bay Member. Foraminifera are more common than ostracods (Tables 5, 6), although richness and diversity are generally low in both microfossil groups. Despite this, there is a clear change from a High Arctic assemblage in L1 to low Boreal-Lusitanian (sensu Feyling-Hanssen 1955) sub-littoral microfaunal assemblages in L3 and L4 (Table 8).

Of the foraminifera species recorded in L1, E. excavatum clavatum and B. frigida are characteristic of cold, shallow water conditions, such as those associated with the Lateglacial interval (e.g. Holmes 1977; Thomson 1978; Knudsen 1985; Jensen \& Knudsen 1988; Merritt et al. 1995; Eiríksson et al. 2004). This assemblage is thus considered to be pre-Holocene, which is consistent with the Younger Dryas Stadial age determined for L1 (Tables 7, 8).

In contrast to L1, higher diversity foraminiferal assemblages are preserved in L3 and L4, dominated by A. batavus (Table 5), which is a temperate species that is generally regarded as a good indicator of postglacial conditions. Its modern distribution around Britain is in brackish (salinity of $22 \%$ ) to fully marine (35\%) settings, with water depths ranging from $<10$ to 60 m (Murray 1992). The presence of B. elongata, B. marginata, E. scaber and $H$. 
anglica are further indicators of a temperate, sub-littoral environmental regime, with the latter two species having a preference for brackish marine salinities.

Whereas L3 was almost devoid of ostracods in the samples analysed, increased numbers and diversity characterise L4 (Table 6). The most abundant species listed in Table 6, including E. concinna and S. bradii, are commonly found in the present-day North Sea (Athersuch et al. 1989), in water depths from 5 to $200 \mathrm{~m}$. By way of contrast, $H$. viridis and $L$. psammophila are common species around the coast of Britain in brackish (outer estuarine) to marine settings (Athersuch et al. 1989).

\section{Depositional environment}

Lithozone 1. - On the basis of its relatively coarse-grained and lithic-rich nature, its sparse high-arctic microfauna, and an age determination of $10543 \pm 55{ }^{14} \mathrm{C}$ yr BP, we interpret L1 to have been deposited as a lowstand fluvio-deltaic wedge during the Younger Dryas Stadial. The offshore limits of L1 (Fig. 3A) are consistent with the wedges having been sourced from rivers draining the east and northeast Scottish hinterland; principally the River Tay catchment system in the south, and the North Esk-South Esk catchment system in the north, which enters into the North Sea from the embayed area of the coastline to the north and south of Montrose (Fig. 1). Although the wedge has been subsequently eroded, its top - the delta plain - would have been located no deeper than about -30 m OD (its present erosional level) (Figs 4, 5). From this, we infer a fall in relative sea level to between -20 and -30 OD during the deposition of L1 (Fig. 10). 
Lithozones 2-4. - On the basis of seismic facies analysis, we suggest that L2 displays common attributes (clinoform profile and dip) with L3 and L4, and thus that these wedges share a common origin. The radiocarbon dates indicate a mid- to late Holocene age for L3 and L4, which is not inconsistent with the microfaunal and macrofaunal (in L4) assemblages that reveal a temperate sub-littoral environment, with relative sea level slightly higher than the present-day (Fig. 10). Intriguingly, the majority of the foraminifera and ostracods are euryhaline and tolerant of brackish marine conditions, which may reflect some freshwater input. Whilst there are compositional similarities between the sediments of L1 and those of L3 and L4, the latter reveal a greater textural maturity that is more consistent with marine reworking of L1-type sediments, in response to the change in hydrodynamic conditions. Although some fluviatile input cannot be discounted, we interpret the L2-L4 sequence in terms of a prograding series of highstand shoreface wedges largely derived by marine reworking of older Quaternary sediments, including L1. Arguably, the landward (topset) part of each wedge has been eroded during the succeeding phase of shoreface development. In Fig. 3A, the limits of L2 to L4 imply both a seaward progradation as well as a longshore (to the NE) migration. This is consistent with the direction of sand transport offshore NE Scotland as deduced by bedforms (Kenyon \& Stride 1970) (Fig. 1B).

\section{Discussion}

Any attempt to understand Lateglacial-Holocene landscape development in eastern Scotland has to take into consideration the coastal marine record of change. Our study has revealed that a highly dynamic sedimentary regime has prevailed along the eastern Scottish seaboard during and since deglaciation of the last British Ice Sheet. The coastal marine landform record is dominated by the sequential growth of a prograding sediment wedge, initiated as a 
lowstand fluvio-delta deposit (L1) during the Younger Dryas Stadial, with growth sustained by episodic mid- to late Holocene shoreface progradation (L2-L4). On the basis of radiocarbon age data, we infer a hiatus between $\mathrm{L} 1$ and $\mathrm{L} 2$, though its duration remains uncertain. In Fig. 10, the lithozones are incorporated within an event stratigraphy that places their timing of formation in relation to changes in relative sea level, North Sea hydrography and palaeogeography, and North East Atlantic oceanography. In the following discussion, this event-stratigraphic framework provides the basis for assessing (1) Lateglacial palaeogeography and base level, and (2) the factors controlling Holocene shoreface progradation off eastern Scotland.

\section{Lateglacial palaeogeography and base level}

The nature and age of L1 provide unequivocal evidence for the existence of a lowstand fluviodeltaic wedge occupying the present-day coastal embayments seaward of the Firth of Tay estuary and Montrose (Figs 1, 3), during the Younger Dryas Stadial (Fig. 10). From mapping and interpretation of the seismic data, we suggest that the seaward edge of the former delta plain may have been at a present depth of about -20 to $-30 \mathrm{~m}$ OD. Consequently, the coastline of eastern Scotland, between Fife Ness and Inverbervie (Fig. 1), would have been 5 to $10 \mathrm{~km}$ east of the modern coastline. The seaward limit of L1 depicted in Fig. 3 gives a maximum approximation of the Younger Dryas Stadial coastline.

Elsewhere, a $600 \mathrm{~m}$-wide submarine rock platform has been located offshore to the SE of North Berwick (Fig. 1) by diver observation and on echo-sounder records where it occurs down to a depth of $-27 \mathrm{~m}$ below OD (Eden et al. 1969). This platform rises gently from -27 m OD to a shoreline at $-18 \mathrm{~m}$ OD; the latter has been equated by Sissons (1974) with the 
Main Lateglacial Shoreline. A deeper lowstand base level is also supported by onshore borehole evidence that has revealed buried channels around the Firth of Tay region that are incised into the essentially planar Main Lateglacial Shoreline to a depth of $-29 \mathrm{~m}$ below OD (Paterson et al. 1981). The River Tweed in NE England is also reported to have cut channels down to a depth of $-20 \mathrm{~m}$ below OD during the same interval (Rhind 1972). This base level probably corresponds with the maximum readvance of ice caps during the Younger Dryas Stadial (Sissons 1974; Jardine 1979; Paterson et al. 1981).

The significance of this observation is that the lowstand wedge, together with published evidence for Lateglacial marine erosion in eastern Scotland (Eden et al. 1969; Sissons 1974), suggests a relative sea level of -20 to -30 m OD for the Younger Dryas Stadial. This base level is at least $10 \mathrm{~m}$ lower than previously published estimates of relative sea level in this interval for this region (Paterson et al. 1981; Sissons 1983; Shennan \& Horton 2002; Hansom \& McGlashan 2004; Shennan et al. 2006).

Mid- to late Holocene shoreface progradation

The sedimentary regime offshore eastern Scotland underwent a significant change during the early to early mid-Holocene in response to: (1) the rise in eustatic sea level; and, (2) the onset of the modern North Sea circulation pattern (Fig. 10). The interval between about 10000 and $6000{ }^{14} \mathrm{C}$ yr BP is marked by an overall rising sea level and the development of a transgressive systems tract in the North Sea region, which inundated eastern Scotland beyond the present coast from about 8000 to $7500{ }^{14} \mathrm{C}$ yr BP (Jardine 1979; Paterson et al. 1981). The erosion of lithozone L1 may have been instigated during transgression. Since about $7500{ }^{14} \mathrm{C}$ 
yr BP, estuarine silts and clays have accumulated along the inundated coastal fringe (Paterson et al. 1981), whereas a sub-littoral environment has prevailed in the study area.

In the early mid-Holocene, the changing palaeogeography of the North Sea region (opening of English Channel; isolation and submergence of Dogger Bank) (Eisma et al. 1981; Lambeck 1995; Shennan et al. 2000; Behre 2007) combined with the increased inflow from the NE Atlantic Ocean (Lehman \& Keigwin 1992; Harland \& Howe 1995; Longva \& Thorsnes 1997; Klitgaard-Kristensen et al. 2001; Hebbeln et al. 2006) (Fig. 10) led to the establishment of the modern circulation system. This generated strong coastal currents around the North Sea, including Scottish coastal water (Harland \& Long 1996; Evans et al. 2002) (Fig. 1A). Thus, our interpretation of L2 to L4 as a prograding series of highstand shoreface wedges is consistent with a tidally-influenced coastal zone.

In order to evaluate the factors responsible for controlling the development of the shoreface wedges, a number of key features must be considered:

- At the scale of the lithozone (L2 to L4), each seismically distinct depositional package represents a temporally separate pulse of sedimentation that may last for at least 1000 years (e.g. L4: $2224 \pm 54$ to $1377 \pm 53{ }^{14} \mathrm{C}$ yr BP: extent of recent activity - if any - is uncertain), and may be separated by intervals in excess of 2000 years (e.g. L3 and L4) (Fig. 10).

- Each lithozone may itself consist of higher-order units that possibly represent component beds or bedsets. In L4, stratigraphic superposition is revealed by variation in sediment composition in core 56-03/586 (Fig. 9B), particularly with respect to monocrystalline quartz. 
- The microfaunal assemblage recovered from L3 and L4 indicate that although salinity was probably close to fully marine, the presence of brackish marine conditions from time to time can be postulated.

From these observations, we infer: (1) that higher-order depositional events (beds/bedsets) are superimposed on a longer-term cyclicity (lithozone); and, (2) that salinity during these depositional cycles may have been periodically diluted by freshwater input. Bearing in mind that the general depositional environment offshore eastern Scotland is predominantly influenced by tidal currents, it would seem sensible to consider the cyclical nature of sedimentation in relation to the strength of Atlantic inflow. According to Harland \& Howe (1995), fluctuations in the relative proportions of dinoflagellate cyst populations indicate significant oceanographic changes along the Atlantic margin of NW Britain between 8000 and $6000{ }^{14} \mathrm{C}$ yr BP, and between 4000 and $2000{ }^{14} \mathrm{C}$ yr BP, with increased strength of the North Atlantic Drift Current during these intervals. It thus seems reasonable to assume that Atlantic inflow into the North Sea was similarly increased at these times. Although no direct correlation between these events and the deposition of L2 to L4 can be made at this time, in part due to the rather general dating of the dinoflagellate cyst record, the proposed duration of these oceanographic events is comparable to the longer term cyclicity envisaged for each lithozone.

As the North Atlantic Drift Current is a wind-driven extension of the North Atlantic Current, any strengthening of the current would coincide with an increase in the strength of the westerly winds blowing across the North Atlantic (Kershaw, 2000). Moreover, it has long been established that a strong westerly circulation is linked to phases of increased rainfall over NW Europe (Walker \& Bliss 1932). Thus, it is tempting to suggest that this may lead to 
increased freshwater input to the coastal zone via rivers and estuaries thereby reducing nearshore salinity as recorded by the microfauna offshore eastern Scotland. Mayewski et al. (2004) have recently proposed at least six major global intervals of rapid climate change within the Holocene; these are: 9000-8000; 6000-5000; 4200-3800; 3500-2500; 1200-1000; and, 600-150 cal. yr. All of these intervals, excepting the 600-150 cal. yr, are associated with intensified westerly flow. Intriguingly, the calibrated age for L3 (5681 $\pm 62-5665 \pm 56$ cal. yr) (Table 6) falls within one of the proposed intervals of change, whereas L4 (2243 $\pm 78-$ $2237 \pm 80$ and $1294 \pm 31$ cal. yr) lies between the $3500-2500$ and $1200-1000$ cal. yr intervals. Although at this stage we remain cautious about such correlations, they do offer a potential set of large-scale boundary conditions that may account for the observed local cyclicity and hydrology within the mid- to late Holocene succession.

\section{Conclusions}

Detailed analysis of a prograding sediment wedge (St Andrews Bay Member, Forth Formation) offshore eastern Scotland enables the following conclusions to be presented with regard to the Lateglacial-Holocene evolution of this region:

- The prograding sediment wedge was initiated as a fluvio-deltaic lowstand deposit (L1) during the Younger Dryas Stadial. Relative sea level at this time is inferred to be between -20 and $-30 \mathrm{~m} \mathrm{OD}$, which is at least $10 \mathrm{~m}$ lower than previously published estimates.

- Construction of the sediment wedge was renewed and sustained through the mid- to late Holocene by sub-littoral tidal processes that deposited three discrete, highstand, shoreface wedges (L2-L4), which display both seaward progradation and longshore (to 
the NE) migration. Petrographic studies indicate derivation of sediment by local reworking of older Quaternary deposits, including L1, and the contemporary reworking of the sediment wedge as it migrated, especially the topset zone.

- Individual shoreface wedges may represent a depositional cyclicity with a predominant duration of about 1000 years separated by hiatuses of 1000 to 2000 years. These phases of sedimentation are tentatively linked to periods of strong westerly winds driving an enhanced influx of Atlantic water into the North Sea, which in turn drives the North Sea circulation pattern. Increased rainfall during these intervals may also have contributed to periodic freshening of the coastal zone off eastern Scotland via fluviatile and estuarine input, resulting in the brackish marine environment recorded by the microfauna. However, correlation with the postulated global periods of Holocene rapid climate change remains unclear.

Acknowledgements. - We thank Tom Bradwell and Alan Stevenson for their comments on an earlier version of this manuscript. Robert Gatliff and Martin Smith are thanked for their continuing support of the project. Mark Garnett at the NERC radiocarbon laboratory in East Kilbride, Glasgow, undertook the AMS radiocarbon dating. The focus of the paper was greatly improved by the comments of the two referees, Tjeerd van Weering and Ian Shennan. The paper is published with the permission of the Executive Director of the British Geological Survey (NERC). 


\section{References}

Andrews, J.T. \& Dugdale, R.E. 1970: Age prediction of glacio-isostatic strandlines based on their gradiets. Bulletin of the Geological Society of America 81, 3769-3771.

Athersuch, J., Horne, D.J. \& Whittaker, J.E. 1989: Marine and Brackish water ostracods (superfamilies Cypridacea and Cytheracea). Synopses of the British Fauna (New Series) 43, 343 pp.

Behre, K.-E. 2007: A new Holocene sea-level curve for the southern North Sea. Boreas 36, 82-102.

Bradwell, T., Stoker, M.S., Golledge, N., Wilson, C.K., Merritt, J., Long, D., Everest, J., Hestvik, O.B., Stevenson, A., Hubbard, A., Finlayson, A. \& Mathers, H. 2008: The Last British Ice Sheet: maximum extent and demise. Earth Science Reviews 88, 207-226.

Brew, D.S. 1996: Late Weichselian to early Holocene subaqueous dune formation and burial off the North Sea Northumberland coast. Marine Geology 134, 203-211.

Cullingford, R.A. 1977: Lateglacial raised shorelines and deglaciation in the Earn-Tay area. In Gray, J.M \& Lowe, J.J. (eds.): Studies in the Scottish Lateglacial Environment, 15-32. Pergamon Press, Oxford.

Cullingford, R.A. \& Smith, D.E. 1980: Late Devensian raised shorelines in Angus and Kincardineshire, Scotland. Boreas 9, $21-38$.

Dickinson, W.R. \& Suczek, C.A. 1979: Plate tectonics and sandstone compositions: American Association of Petroleum Geologists Bulletin 63, 2164-2182.

Eden, R.A., Carter, A.V.F. \& McKeown, M.C. 1969: Submarine examination of Lower Carboniferous strata on inshore regions of the continental shelf of south-east Scotland. Marine Geology 7, 235-251.

Eiríksson, J., Knudsen, K. L. \& Símonarson, L. A. 2004: Lateglacial oceanographic conditions off Southwest Iceland inferred from shallow-marine deposits in Reykjavi'k and Seltjarnarnes Peninsula. Boreas 33, 269-283.

Eisma, D., Mook, W.G. \& Laban, C. 1981: An early Holocene tidal flat in the Southern Bight. In Nio, S.-D., Schüttenhelm, R.T.E. \& Weering, T.C.E. van (eds.): Holocene Marine Sedimentation in the North Sea Basin. International Association of Sedimentologists Special Publication 5, 229-237.

Evans, J.R., Austin, W.E.N., Brew, D.S., Wilkinson, I.P. \& Kennedy, H.A: 2002. Holocene shelf sea evolution offshore northeast England. Marine Geology 191, 147-164.

Fairbanks, R.G., Mortlock, R.A., Chiu, T.C., Kaplan, A., Guilderson, T.P., Fairbanks, T.W. \& Bloom, A.L: 2005. Marine radiocarbon calibration curve spanning 0 to 50,000 years B.P. based on paired ${ }^{230} \mathrm{Th} /{ }^{234} \mathrm{U} /{ }^{238} \mathrm{U}$ and ${ }^{14} \mathrm{C}$ dates on pristine corals. Quaternary Science Reviews 24, 1781-1796.

Ferentinos, G. \& McManus, J. 1981: Nearshore processes and shoreline development in St Andrews Bay, Scotland, UK. In Nio, S.-D., Schüttenhelm, R.T.E. \& Weering, T.C.E. van (eds.): Holocene Marine Sedimentationin the North Sea Basin. International Association of Sedimentologists Special Publication 5, 161-174.

Feyling-Hanssen, R.W. 1955: Stratigraphy of the marine Late Pleistocene of Billefjorden, Vestspitsbergen. Norsk Polarinstitutt Skrifter 107, 1-186.

Gatliff, R.W., Richards, P.C., Smith, K., Graham, C.C., McCormac, M., Smith, N.J.P., Long, D., Cameron, T.D.J., Evans, D., Stevenson, A.G., Bulat, J. \& Ritchie, J.D. 1994: United Kingdom offshore regional report: the geology of the central North Sea. 118 pp. HMSO for the British Geological Survey, London.

Golledge, N.R. \& Stoker, M.S. 2006: A palaeo-ice stream of the British Ice Sheet in eastern Scotland. Boreas 35, $231-243$. 
Gray, J.M. \& Lowe, J.J. 1977: Studies in the Scottish Lateglacial Environment. 197 pp. Oxford, Pergamon Press.

Gyllencreutz, R., Backman, J., Jakobsson, M., Kissel, C. \& Arnold, E. 2006: Postglacial palaeoceanography in the Skagerrak. The Holocene 16, 975-985.

Hansom, J.D. 1999: The coastal geomorphology of Scotland: understanding sediment budgets for effective coastal management. In Baxter, J., Duncan, K., Atkins, S. \& Lees, G. (eds.): Scotland’s Living Coastline, 33-44. The Stationery Office, Edinburgh.

Hansom, J.D. \& McGlashan, D.J. 2004: Scotland's coast: understanding past and present processes for sustainable management. Scottish Geographical Journal 120, 99-116.

Harkness, D.D. 1983: The extent of natural 14C deficiency in the coastal environment of the United Kingdom. Proceedings of the First International Symposium on C-14 and Archaeology, 351-364. PACT 8.

Harland, R. \& Howe, J.A. 1995: Dinoflagellate cysts and Holocene oceanography of the northeastern Atlantic Ocean. The Holocene 5, 220-228.

Harland, R. \& Long, D. 1996: A Holocene dinoflagellate cyst record from offshore north-east England. Proceedings of the Yorkshire Geological Society 51, 65-74.

Hebbeln, D., Knudsen, K-L., Gyllencreutz, R., Kristensen, P., Klitgaard-Kristensen, D., Backman, J., Scheurle, C., Jiang, H., Gil, I., Smelror, M., Jones, P.D. \& Sejrup, H.P. 2006: Late Holocene coastal hydrographic and climate changes in the eastern North Sea. The Holocene 16, 987-1001.

Holmes, R. 1977: Quaternary deposits of the central North Sea: 5. The Quaternary geology of the UK sector of the North Sea between $56^{\circ}$ and $58^{\circ}$ N. Report of the Institute of Geological Sciences 77/14, $50 \mathrm{pp}$.

Jardine, W.G. 1979: The western (United Kingdom) shore of the North Sea in Late Pleistocene and Holocene times. In Oele, E., Schüttenhelm, R.T.E. \& Wiggers, A.J. (eds.): The Quaternary History of the North Sea, 159-174. Acta University Uppsala Symposium, University Uppsala, Annum Quingentesimum Celebrantis 2, Uppsala.

Kenyon, N.H. \& Stride, A.J. 1970: The tide-swept continental shelf sediments between the Shetland Isles and France. Sedimentology 14, 159-173.

Kershaw, S. 2000: Oceanography: An Earth Science Perspective. 276 pp. Stanley Thornes Publishers Ltd, Gloucester.

Klitgaard-Kristensen, D., Sejrup, H.P. \& Haflidason, H. 2001: The last 18 kyr fluctuations in Norwegian Sea surface conditions and implications for the magnitude of climatic change: evidence from the North Sea. Palaeoceanography 5 , 455-467.

Knudsen, K.L. 1985: Foraminiferal stratigraphy of Quaternary deposits in the Roar, Skjold and Dan fields, central North Sea. Boreas 14, 311-324.

Knudsen, K.L., Conradsen, K., Heier-Nielsen, S. \& Seidenkrantz, M.-S. 1996: Quaternary palaeoceanography and palaeogeography in northern Denmark: a review of the results from the Skagen cores. Bulletin of the Geological Society of Denmark 43, 455-567.

Koç, N., Jansen, E. \& Haflidason, H. 1993: Palaeoceanographic reconstructions of surface ocean conditions in the Greenland, Iceland and Norwegian seas through the last 14 ka based on diatoms. Quaternary Science Reviews 12, 115-140.

Lambeck, K. 1995: Late Devensian and Holocene shorelines of the British Isles and North Sea from models of glacio-hydroisostatic rebound. Journal of the Geological Society, London 152, 437-448. 
Lee, A.J. \& Ramster, J.W. 1981: Atlas of the Seas around the British Isles. Ministry of Agriculture, Fisheries and Food, Lowestoft.

Lehman, S.J. \& Keigwin, L.D. 1992: Sudden changes in North Atlantic circulation during the last deglaciation. Nature 356, $757-762$.

Lehman, S.J., Jones, G.A., Keigwin, L.D., Andersen, E.S., Butenko, G. \& Østmo, S-R. 1991: Initiation of Fennoscandian ice sheet retreat during the last deglaciation. Nature 349, 513-516.

Longva, O. \& Thorsnes, T. 1997: Skagerrak in the past and at the present - an integrated study of geology, chemistry, hydrography and microfossil ecology. Norges Geologiske Undersøkelse Special Publication 8, 100 pp.

Mangerud, J., Andersen, S.T., Berglund, B.E. \& Donner, J.J. 1974: Quaternary stratigraphy of Norden, a proposal for terminology and classification. Boreas 3, 109-128.

Mayewski, P.A., Rohling, E.E., Stager, J.C., Karlén, W., Maasch, K.A., Meeker, L.D., Meyerson, E.A., Gasse, F., van Kreveld, S., Holmgrem, K., Lee-Thorp, J., Rosqvist, G., Rack, F., Staubwasser, M., Schneider, R.R. \& Steig, E.J. 2004 : Holocene climate variability. Quaternary Research 62, 243-255.

Merritt, J.W., Auton, C.A. \& Firth, C.R. 1995: Ice-proximal glaciomarine sedimentation and sea-level change in the Inverness area, Scotland: a review of the deglaciation of a major ice stream of the British late Devensian ice sheet. Quaternary Science Review 14, 289-329.

Mitchum, R.M., Vail, P.R. \& Sangree, J.B. 1977: Seismic stratigraphy and global changes of sea level, part 6: stratigraphic interpretation of seismic reflection patterns in depositional sequences. In Payton, C. (ed.): Seismic Stratigraphy applications to hydrocarbon exploration, 117-133. American Association of Petroleum Geologists, Memoir 26.

Murray, J.W. 1992: Distribution and population dynamics of benthic foraminifera from the southern North Sea. Journal of Foraminiferal Research 22, 114-128.

Owens, R. 1981: Holocene sedimentation in the North-western North Sea. In Nio, S.-D., Schüttenhelm, R.T.E. \& Weering, T.C.E. van (eds.): Holocene Marine Sedimentation in the North Sea Basin, 303-322. International Association of Sedimentologists Special Publication 5.

Pantin, H.M. 1991: The sea-bed sediments around the United Kingdom: their bathymetric and physical environment, grain size, mineral composition and associated bedforms. British Geological Survey Research Report SB/90/1, 47 pp.

Paterson, I.B. 1974: The supposed Perth Readvance in the Perth district. Scottish Journal of Geology 10, 53-66.

Paterson, I.B., Armstrong, M. \& Browne, M.A.E. 1981: Quaternary estuarine deposits in the Tay-Earn area, Scotland. Report of the Institute of Geological Sciences 18, 35 pp.

Rhind, D.W. 1972: The buried valley of the lower Tweed. Transactions of the Natural History Society of Northumberland, Durham and Newcastle-upon-Tyne 41, 159-164.

Salvador, A. 1994: International Stratigraphic Guide. A guide to stratigraphic classification, terminology, and procedure. Second Edition. The International Union of Geological Sciences and The Geological Society of America (Colorado).

Sangree, J.M. \& Widmier, J.M. 1977: Seismic stratigraphy and global changes of sea level, part 9: seismic interpretation of clastic depositional facies. In Payton, C. (ed.): Seismic Stratigraphy - applications to hydrocarbon exploration, 165184. American Association of Petroleum Geologists, Memoir 26.

Shennan, I. \& Horton, B. 2002: Holocene land- and sea-level changes in Great Britain. Journal of Quaternary Science 17, $511-526$. 
Shennan, I., Lambeck, K., Flather,R., Horton, B., McArthur, J., Innes, J., Lloyd, J., Rutherford, M. \& Wingfield, R. 2000: Modelling western North Sea palaeogeographies and tidal changes during the Holocene. In Shennan, I. \& Andrews, J. (eds.): Holocene Land-Ocean Interaction and Environmental Change around the North Sea, 299-319. Geological Society, London, Special Publications, 166, 299-319.

Shennan, I., Coulthard, T., Flather, R., Horton, B., Macklin, M., Rees, J. \& Wright, M. 2003. Integration of shelf evolution and river basin models to simulate Holocene sediment dynamics of the Humber Estuary during periods of sea-level change and variations in catchment sediment supply. The Science of the Total Environment 314-316, 737-754.

Shennan, I., Bradley, S., Milne, G., Brooks, A., Bassett, S. \& Hamilton, S. 2006: Relative sea-level changes, glacial isostatic modelling and ice sheet reconstructions from the British Isles since the Last Glacial maximum. Journal of Quaternary Science 21, 585-599.

Sissons, J.B. 1974: Late-glacial marine erosion in Scotland. Boreas 3, 41-48.

Sissons, J.B. 1976: The Geomorphology of the British Isles: Scotland. 150 pp. Methuen, London.

Sissons, J.B. 1983: Shorelines and isostasy in Scotland. In Smith, D.E. \& Dawson, A.G. (eds.): Shorelines and Isostasy, 209225. Academic Press, London.

Sissons, J.B., Smith, D.E. \& Cullingford, R.A. 1966: Late-glacial and Post-glacial shorelines in south-east Scotland. Transactions of the Institution of British Geographers 39, 9-18.

Stoker, M.S. 1987: Tay-Forth (56N-04W) Quaternary Geology, 1:250,000 Offshore Map Series, British Geological Survey.

Stoker, M.S., Long, D. \& Fyfe, A.J. 1985: A revised Quaternary stratigraphy for the central North Sea. Report of the British Geological Survey 17, 35 pp.

Stride, A.H., 1973: Sediment transport by the North Sea. In Goldberg, E.D. (ed.): North Sea Science, 101-130.

Thomson, M.E. 1978: IGS studies of the geology of the Firth of Forth and its Approaches. Report of the Institute of Geological Sciences 77/17, 56 pp.

Veum, T., Jansen, E., Arnold, M., Beyer, I. \& Duplessy, J.-C. 1992: Water mass exchange between the North Atlantic and the Norwegian Sea during the past 28,000 years. Nature 356, 783-785.

Walker, G.T. \& Bliss, E.W. 1932: World Weather V. Memoir of the Royal Meteorological Society 4, 53-84. 


\section{Figure captions}

1. A) Map of study area, showing general bathymetry (contours in metres) and location of BGS geophysical profiles and cores. B) General oceanographic circulation pattern in North Sea region (after Longva \& Thorsnes 1997 and Hebbeln et al. 2006: width of arrows indicates relative magnitude of volume transport), and sand transport paths offshore eastern Scotland and England (after Kenyon \& Stride 1970).

2. General stratigraphic framework for the Late Devensian-Holocene inner-shelf succession, offshore eastern Scotland, together with the stratigraphic-range of the BGS cores used in this study. The correlation of the L1 to L4 lithozones is based on the results of this study (see text for details). The 'Lateglacial' spans the time between the retreat of the Main Late Devensian (Weichselian) ice sheet in an area and the beginning of the Holocene (Gray \& Lowe 1977). Subdivision of Holocene taken from Mangerud et al. (1974): note that dates are in ${ }^{14} \mathrm{C}$ kyr BP.

3. A) Distribution and thickness of the St Andrews Bay Member. B) Offshore limits of lithozones 1 to 4.

4. Interpreted line drawings of BGS boomer profiles showing sedimentary architecture and subdivision of the St Andrews Bay Member. Location of sections shown in Fig. 1. Water depth in metres based on acoustic velocity of $1450 \mathrm{~ms}^{-1}$; sub-bottom depth in metres based on acoustic velocity of $1500 \mathrm{~ms}^{-1}$.

5. Wheeler diagram based on the interpretation of BGS profile 80/03-14 (Fig. 4A) illustrating the Late GlacialHolocene prograding shoreface development offshore eastern Scotland, and the relationship of the offshore lithozones of the St Andrews Bay Member to the Main Late Glacial and younger shorelines. Chronostratigraphic positioning of lithozones 1, 2 and 4 based on AMS ${ }^{14} \mathrm{C}$ dates (Table 7); for L2, see text for details. Shoreline information from Paterson et al. (1981). Water depth in metres based on acoustic velocity of $1450 \mathrm{~ms}^{-1}$; sub-bottom depth in metres based on acoustic velocity of $1500 \mathrm{~ms}^{-1}$.

6. Graphic logs of BGS vibrocores 56-03/586 and 56-03/587, and borehole 74/15, illustrating predominant lithology, gross sedimentary structure, positions of subsamples, and dated horizons in lithozones (L) 1, 3 and 4.

7. Bivariant plots (in modal \%) showing the variation in: A) monocrystalline quartz and B) volcanic lithic clasts with respect to polycrystalline quartz; C) volcanic lithic clasts with respect to metamorphic lithic clasts; D) bioclasts, E) biotite and F) muscovite, with respect to monocrystalline quartz. Compositional trends shown by arrows (see text for details).

8. Multicomponent plots showing the variation in sediment composition in: A) Lithozone 1, core 56-03/587; B) Lithozone 3, borehole 74/15; C) Lithozone 4, core 56-03/587; D) Lithozone 4, core 56-03/586; E) Lithozone 4, borehole 74/15. See text for details. Qm - monocrystalline quartz; Qp - polycrystalline quartz; $\mathrm{Pl}$ - plagioclase; Lv - volcanic lithic clasts; Lm- metamorphic lithic clasts; L total - total lithic component; Bio - biotite; $\mathrm{Mu}$ - muscovite; Chl - chlorite; Gt - garnet; Op - opaque minerals; Hb - amphibole; Ep epidote; CC - detrital carbonate minerals (both finely crystalline and micritic); bioclasts - bioclastic debris (e.g. foraminifera, ostracods).

9. Stratigraphical variation in modal \% of mono- and polycrystalline quartz, plagioclase, volcanic and metamorphic lithic clasts, biotite, muscovite and garnet for lithozones 1 and 4 in core 56-03/587 (A), and lithozone 4 in core 56-03/586 (B). See text for details.

10. Late Devensian-Holocene event stratigraphy $\left({ }^{14} \mathrm{C}\right.$ kyr BP) placing offshore eastern Scotland into a wider North Sea-NE Atlantic context. Sea level curves based on Hansom \& McGlashan (2004) and this study (offshore); hydrographic, palaeogeographic and oceanographic details based on numerous sources (see text for references). NADC - North Atlantic Drift Current.

\section{Table captions}

1. Core location data 
2. Petrography of the sands and silts recovered in BGS vibrocores 56-03/586, 56-03/587 and borehole 74/15. *Separate samples within drilled interval.

3. Compositional data (calculated as modal \%) for the sands and silts recovered in BGS vibrocores 56-03/586, 56-03/587 and borehole 74/15. Qm - monocrystalline quartz; Qp - polycrystalline quartz; Pl - plagioclase; Ksp - K-feldspar; Lv - volcanic lithic clasts; Ls - sedimentary lithic clasts; Lm- metamorphic lithic clasts; L total - total lithic component; Bio - biotite; Mu - muscovite; Chl - chlorite; Gt - garnet; St - staurolite; Op - opaque minerals; Hb - amphibole; Ep - epidote; Ap - apatite; Px - pyroxene; Ctd - chloritoid; CC detrital carbonate minerals (both finely crystalline and micritic); bioclasts - bioclastic debris (e.g. foraminifera, ostracods). N, number of grains point counted; * samples ED10278 and ED10295 too few grains to point count.

4. Summary of key aspects of petrographic and compositional data for lithozones 1,3 and 4 .

5. Distribution of foraminifera in BGS vibrocores 56-03/586, 56-03/587 and borehole 74/15.

6. Distribution of ostracods in BGS vibrocores 56-03/586, 56-03/587 and borehole 74/15.

7. $\mathrm{AMS}{ }^{14} \mathrm{C}$ dates

8. Summary and interpretation of lithozones 1, 3 and 4. Interpretation of lithozone 2 based on seismic association with L3 and L4 (see text for details). 

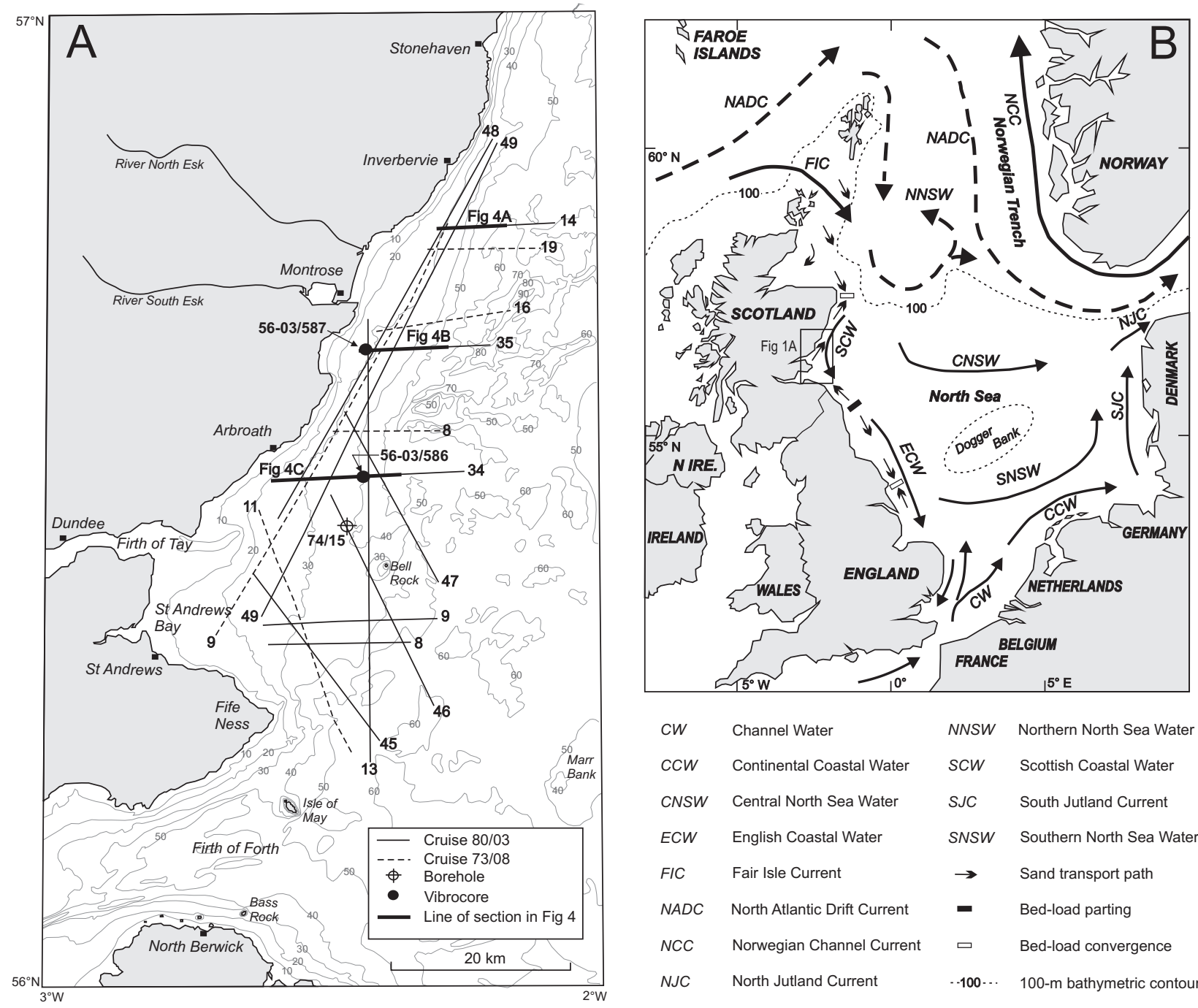

$\begin{array}{llll}\text { CW } & \text { Channel Water } & \text { NNSW } & \text { Northern North Sea Water } \\ \text { CCW } & \text { Continental Coastal Water } & \text { SCW } & \text { Scottish Coastal Water } \\ \text { CNSW } & \text { Central North Sea Water } & \text { SJC } & \text { South Jutland Current } \\ \text { ECW } & \text { English Coastal Water } & \text { SNSW } & \text { Southern North Sea Water } \\ \text { FIC } & \text { Fair Isle Current } & \rightarrow & \text { Sand transport path } \\ \text { NADC } & \text { North Atlantic Drift Current } & - & \text { Bed-load parting } \\ \text { NCC } & \text { Norwegian Channel Current } & \square & \text { Bed-load convergence } \\ \text { NJC } & \text { North Jutland Current } & -\mathbf{- 1 0 0}-. & \text { 100-m bathymetric contour }\end{array}$




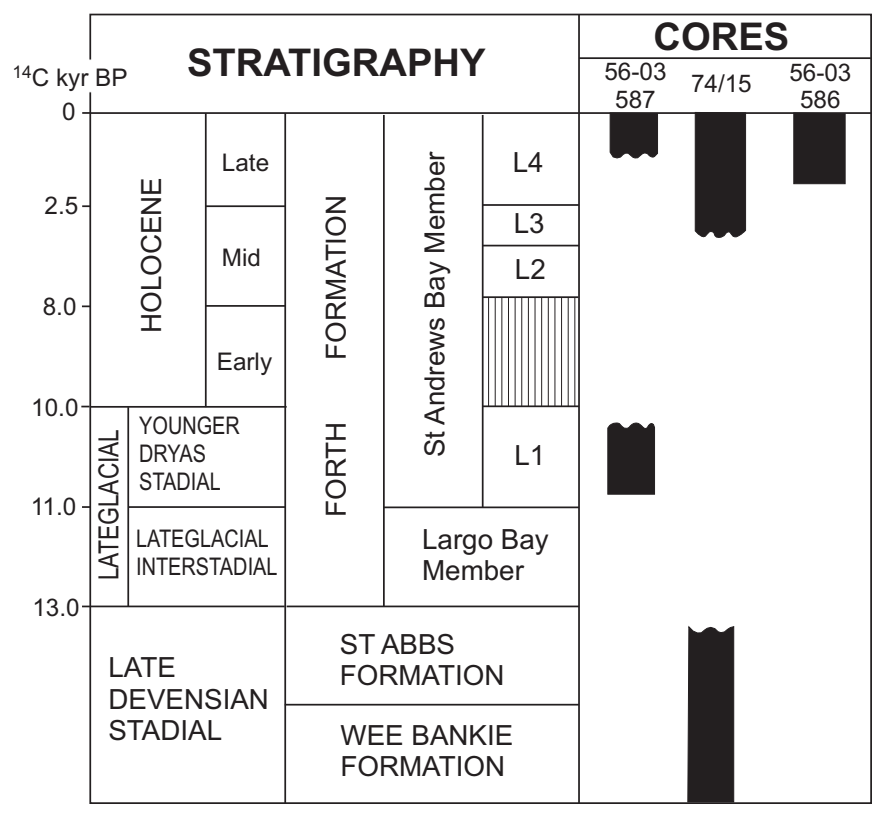



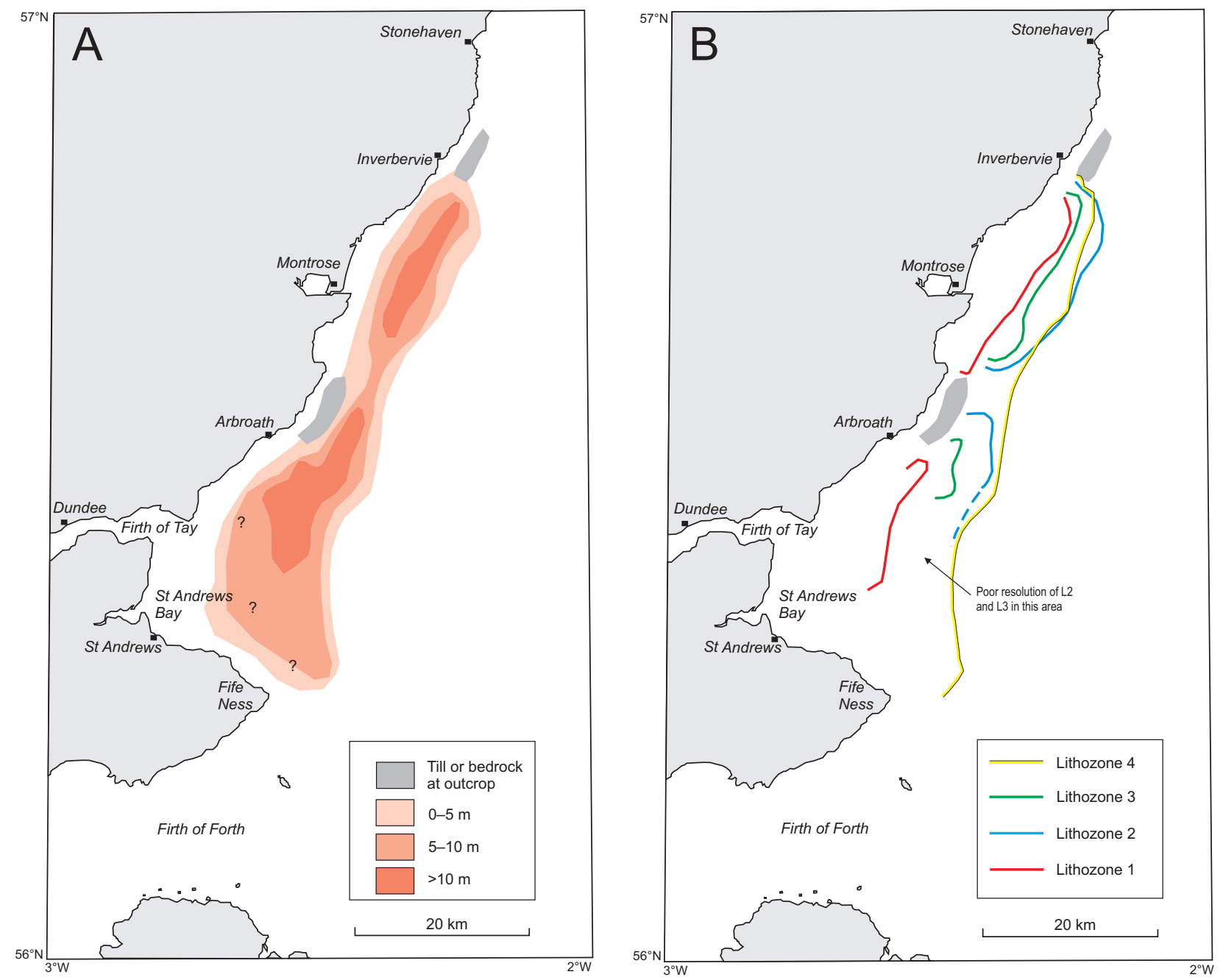


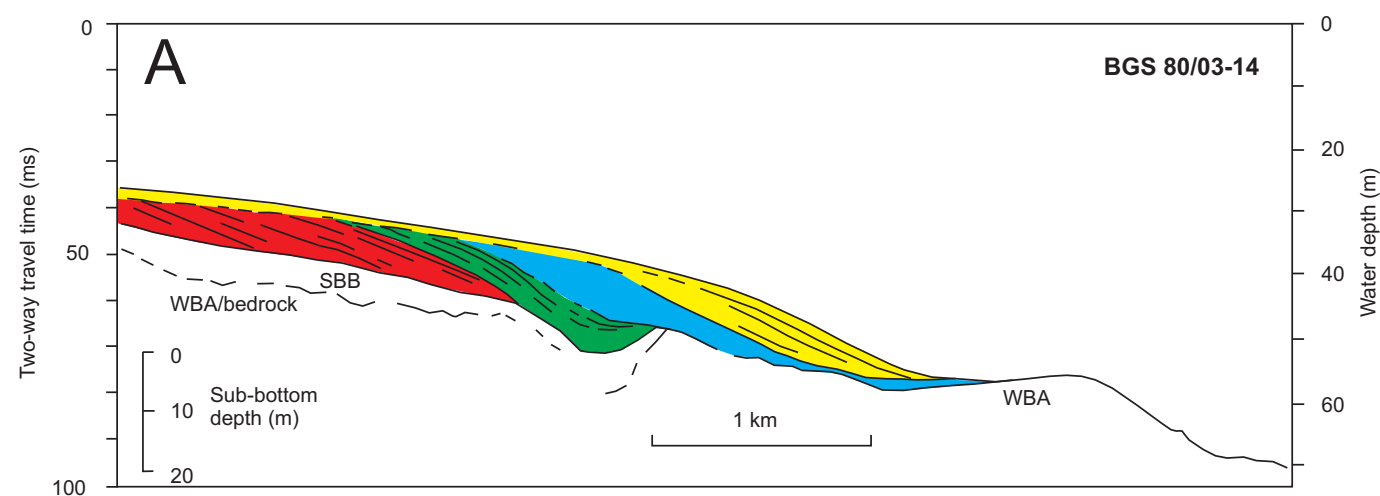

\begin{tabular}{|c|c|c|}
\hline & \multirow[b]{2}{*}{ Lithozone 4} & \multirow{4}{*}{$\begin{array}{l}\text { St Andrews Bay Member } \\
\text { (Forth Formation) }\end{array}$} \\
\hline & & \\
\hline & Lithozone 3 & \\
\hline & Lithozone 2 & \\
\hline & Lithozone 1 & \\
\hline FHG & \multicolumn{2}{|c|}{ Largo Bay Member (Forth Formation) } \\
\hline SBB & \multicolumn{2}{|c|}{ St Abbs Formation } \\
\hline WBA & \multicolumn{2}{|c|}{ Wee Bankie Formation } \\
\hline $74 / 15$ & \multicolumn{2}{|l|}{ BGS borehole } \\
\hline $56-03 / 586$ & \multicolumn{2}{|l|}{ BGS vibrocore } \\
\hline
\end{tabular}
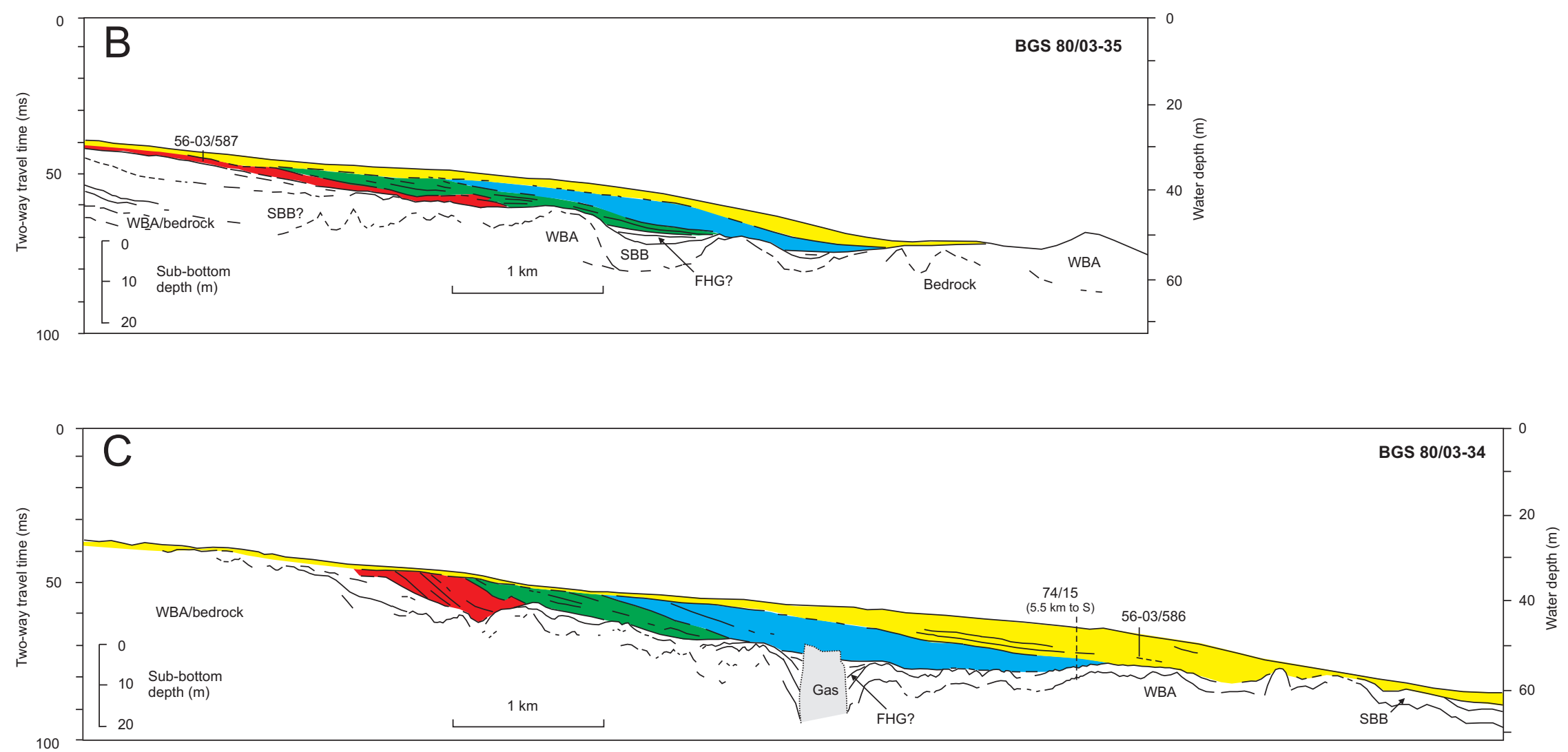

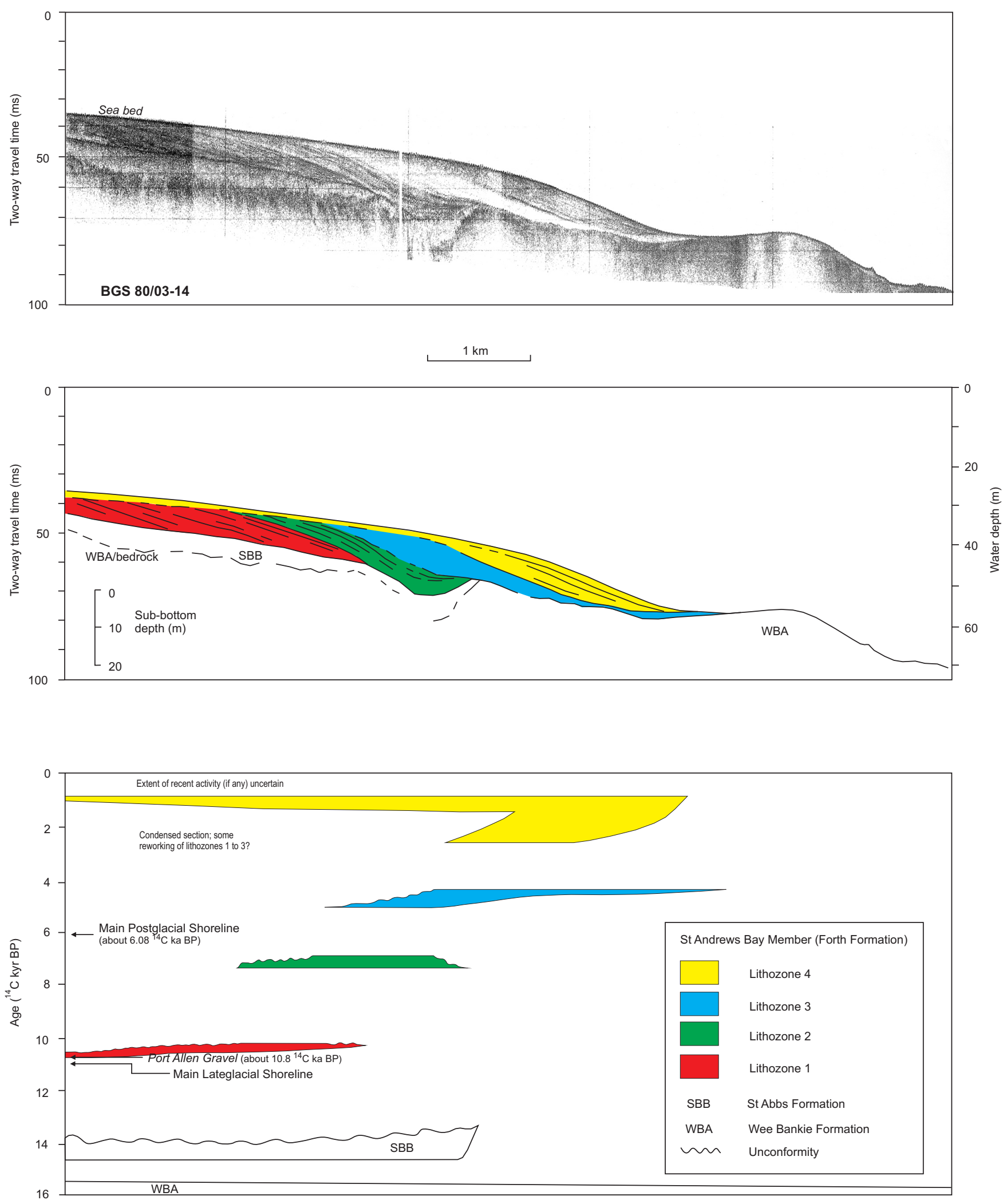


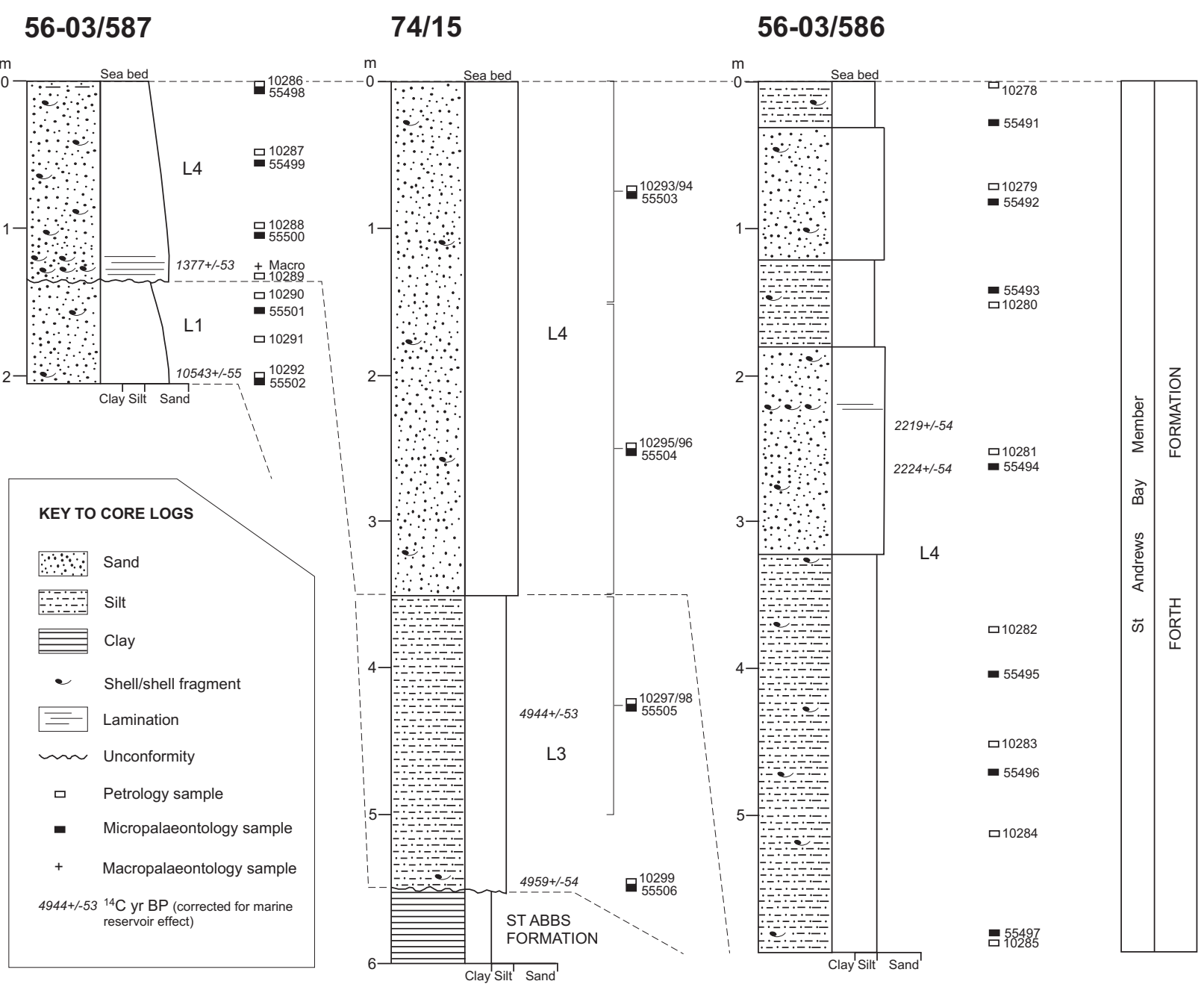



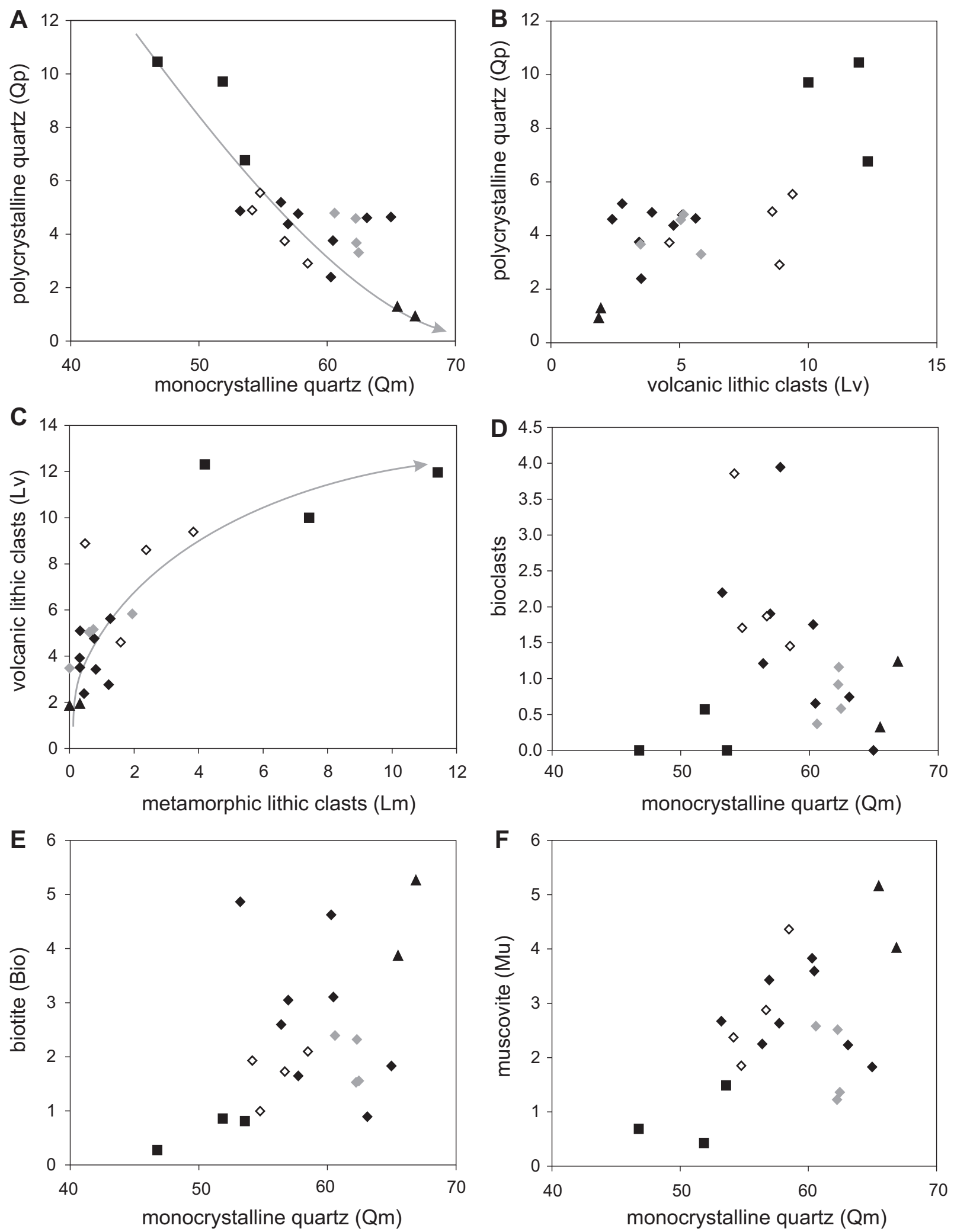

- Lithozone 4 (56-03/586) $\quad$ Lithozone 4 (74/15)

A Lithozone $3(74 / 15)$

$\diamond$ Lithozone 4 (56-03/587) — Lithozone $1(56-03 / 587)$ 


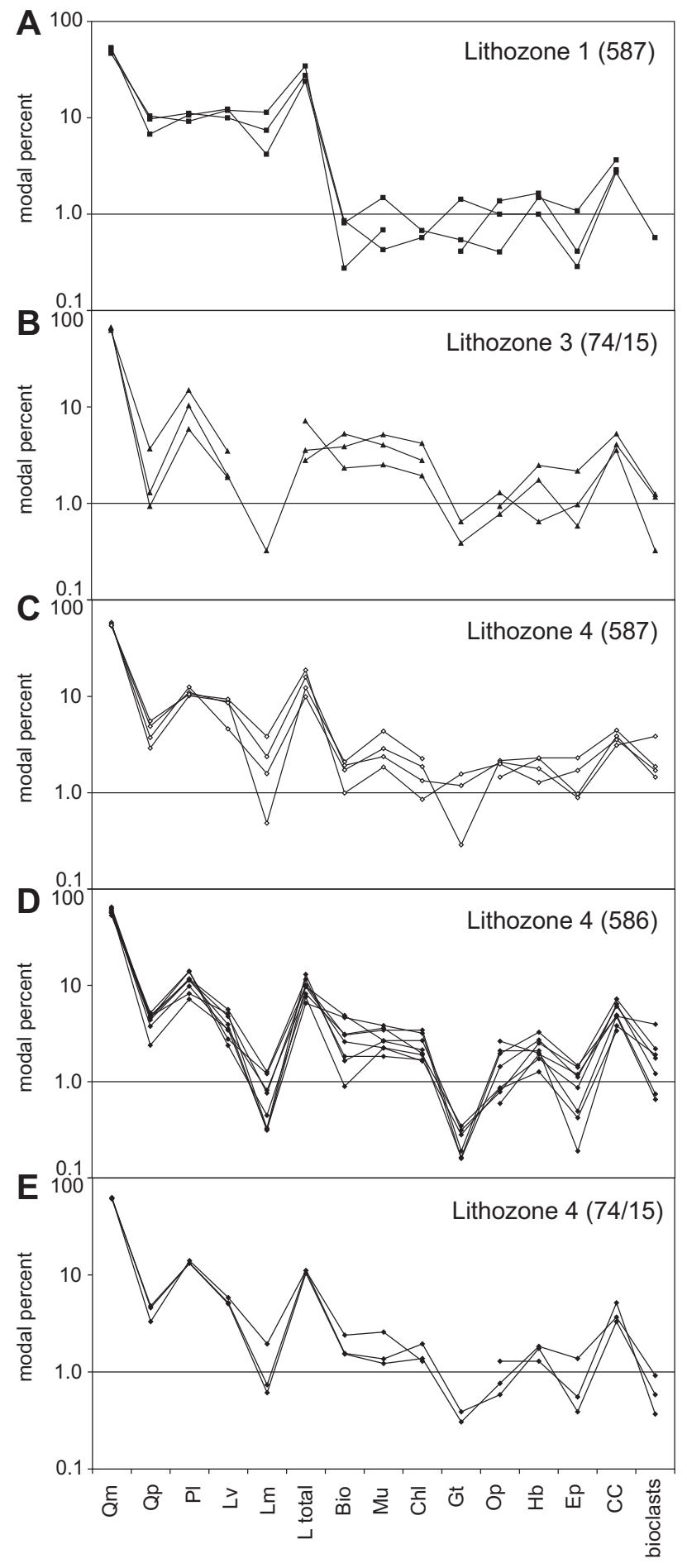


A $56-03 / 587$

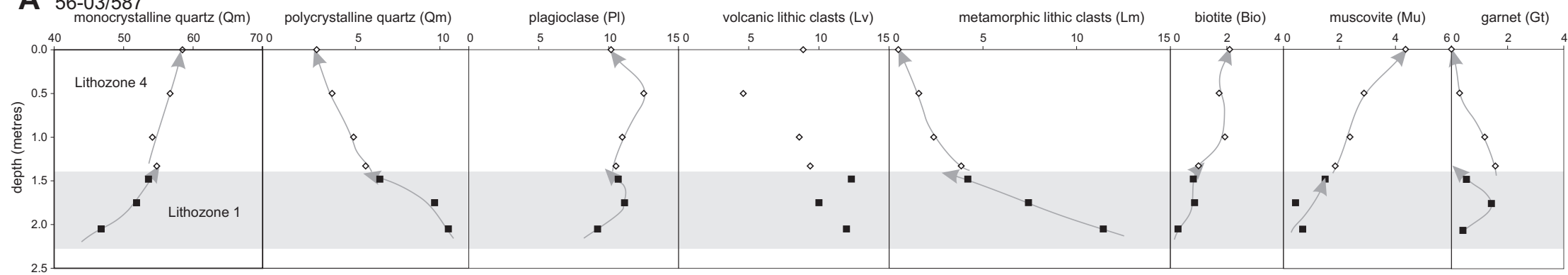

B $56-03 / 586$

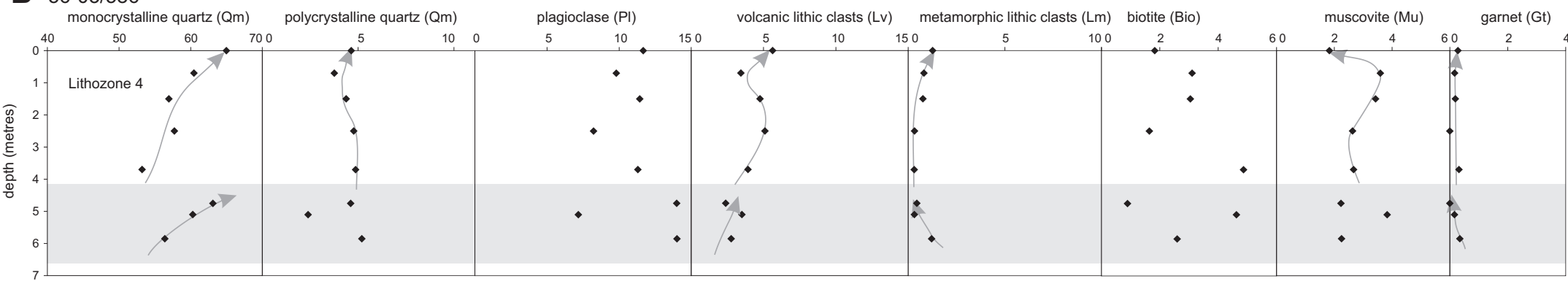




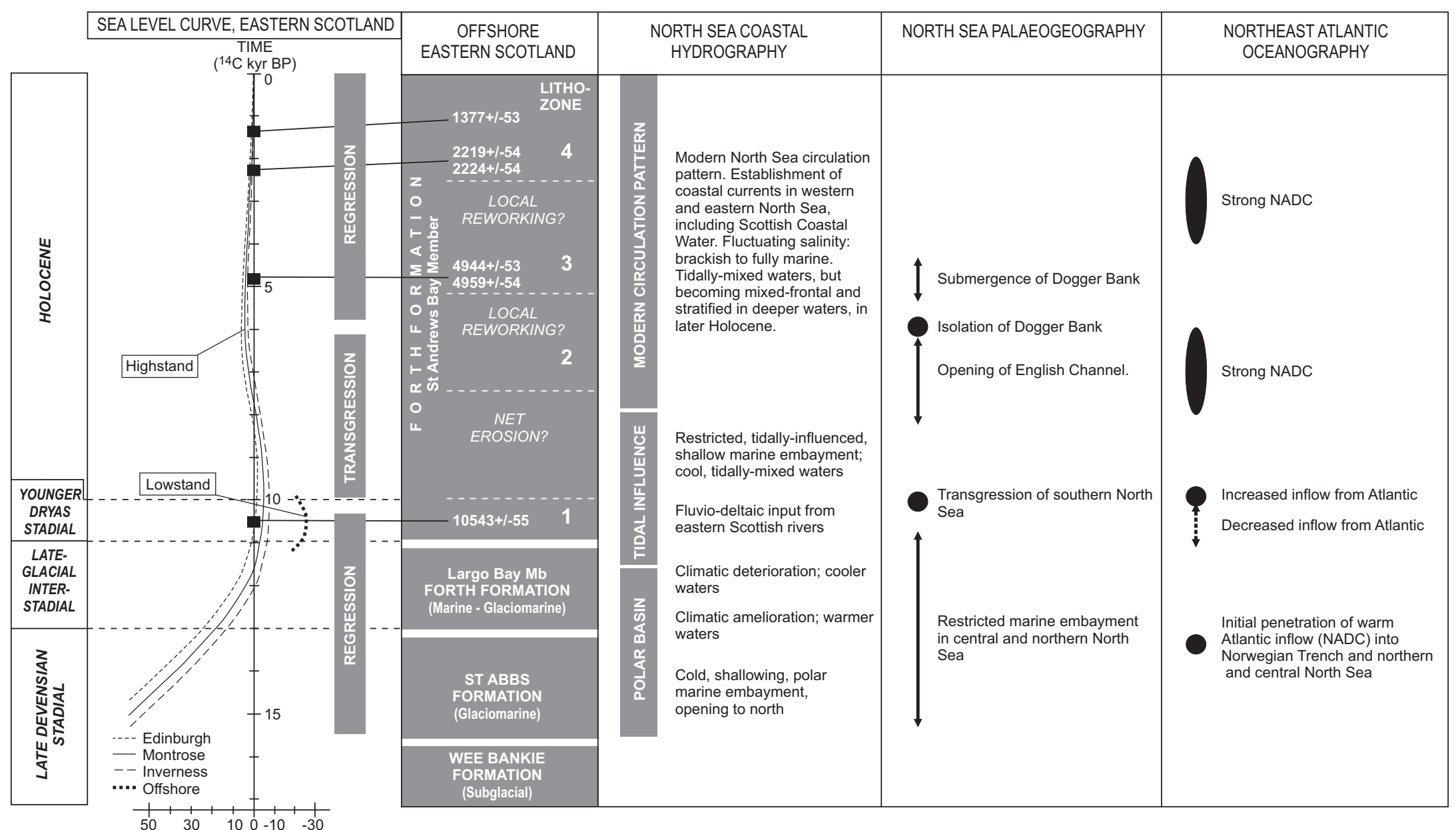

RELATIVE SEA LEVEL (m) 
Table 1. Core location data.

\begin{tabular}{lllll}
\hline $\begin{array}{l}\text { BGS Sample } \\
\text { No. }\end{array}$ & $\begin{array}{l}\text { Latitude } \\
(\mathrm{N})\end{array}$ & $\begin{array}{l}\text { Longitude } \\
(\mathrm{W})\end{array}$ & $\begin{array}{l}\text { Water } \\
\text { Depth } \\
(\mathrm{m})\end{array}$ & $\begin{array}{l}\text { Core } \\
\text { Length } \\
(\mathrm{m})\end{array}$ \\
\hline $56-03 / 586^{*}$ & 56.51576 & 02.42089 & 44 & 5.9 \\
$56-03 / 587^{*}$ & 56.65023 & 02.42221 & 31 & 2.08 \\
$74 / 15^{* *}$ & 56.468 & 02.458 & 35 & $11.0^{+}$ \\
\hline & & & \\
$*$ Vibrocore & & & \\
** Borehole & & & \\
$+\quad$ Total Quaternary thickness (including St Abbs and Wee Bankie Fms)
\end{tabular}


Table 2. Petrography of the sands and silts recovered in BGS vibrocores 56-03/586, 56-03/587 and borehole 74/15. *Separate samples within drilled interval.

\begin{tabular}{|c|c|c|c|c|c|c|c|}
\hline \multirow[t]{2}{*}{ Sample } & \multirow[t]{2}{*}{ BGS core } & \multirow{2}{*}{$\begin{array}{l}\text { Depth } \\
\text { (m) }\end{array}$} & \multirow{2}{*}{$\begin{array}{l}\text { Litho- } \\
\text { Zone }\end{array}$} & \multirow[t]{2}{*}{ Lithology } & \multicolumn{3}{|r|}{ Detrital Components } \\
\hline & & & & & Major & Minor & Accessory \\
\hline ED10278 & 56-03/586 & 0.0 & 4 & $\begin{array}{l}\text { very fine sand } \\
\text { to coarse silt }\end{array}$ & $\begin{array}{l}\text { monocrystalline } \\
\text { quartz }\end{array}$ & $\begin{array}{l}\text { biotite, plagioclase, } \\
\text { polycrystalline quartz, } \\
\text { altered rock fragments }\end{array}$ & $\begin{array}{l}\text { carbonate minerals, opaque minerals, apatite, chlorite, amphibole, garnet, epidote, ?pyroxene, } \\
\text { zoisite/clinozoisite, staurolite, muscovite, zircon, microcline, bioclasts (rare), tourmaline }\end{array}$ \\
\hline ED10279 & 56-03/586 & 0.7 & 4 & very fine sand & $\begin{array}{l}\text { monocrystalline } \\
\text { quartz }\end{array}$ & $\begin{array}{l}\text { biotite, bioclasts, muscovite, } \\
\text { plagioclase }\end{array}$ & $\begin{array}{l}\text { chlorite, opaque minerals, zoisite/clinozoisite, tourmaline, amphibole, carbonate minerals, } \\
\text { chloritoid, epidote, microcline, zircon, ?volcanic rock fragments (rare), glauconitic material, } \\
\text { ?rutile, garnet, ?pyroxene }\end{array}$ \\
\hline ED10280 & $56-03 / 586$ & 1.5 & 4 & $\begin{array}{l}\text { very fine sand } \\
\text { to coarse silt }\end{array}$ & $\begin{array}{l}\text { monocrystalline } \\
\text { quartz }\end{array}$ & $\begin{array}{l}\text { biotite, bioclasts, carbonate } \\
\text { minerals, plagioclase, } \\
\text { altered rock fragments }\end{array}$ & $\begin{array}{l}\text { pyroxene, tourmaline, amphibole, opaque minerals, muscovite, apatite, epidote, chlorite, } \\
\text { polycrystalline quartz, microcline, garnet, K-feldspar, zoisite/clinozoisite, glauconitic material }\end{array}$ \\
\hline ED10281 & 56-03/586 & 2.5 & 4 & very fine sand & $\begin{array}{l}\text { monocrystalline } \\
\text { quartz }\end{array}$ & $\begin{array}{l}\text { bioclasts, biotite, } \\
\text { plagioclase, carbonate } \\
\text { minerals, altered rock } \\
\text { fragments }\end{array}$ & $\begin{array}{l}\text { silt lithic clasts/peloids, opaque minerals, muscovite, zoisite/clinozoisite, amphibole, epidote, } \\
\text { garnet, polycrystalline quartz, ?pyroxene, glauconitic material, zircon, chlorite }\end{array}$ \\
\hline ED10282 & 56-03/586 & 3.7 & 4 & $\begin{array}{l}\text { very fine sand } \\
\text { to coarse silt }\end{array}$ & $\begin{array}{l}\text { monocrystalline } \\
\text { quartz }\end{array}$ & $\begin{array}{l}\text { plagioclase, biotite, } \\
\text { bioclasts, carbonate } \\
\text { minerals, altered rock } \\
\text { fragments }\end{array}$ & $\begin{array}{l}\text { opaque minerals, zircon, polycrystalline quartz, apatite, tourmaline, zoisite/clinozoisite, } \\
\text { chlorite, garnet, perthite, K-feldspar }\end{array}$ \\
\hline ED10283 & $56-03 / 586$ & 4.7 & 4 & $\begin{array}{l}\text { very fine sand } \\
\text { to coarse silt }\end{array}$ & $\begin{array}{l}\text { monocrystalline } \\
\text { quartz }\end{array}$ & $\begin{array}{l}\text { biotite, muscovite, carbonate } \\
\text { minerals, bioclasts, } \\
\text { plagioclase, volcanic rock } \\
\text { fragments }\end{array}$ & $\begin{array}{l}\text { opaque minerals, zircon, amphibole, titanite, garnet, zoisite/clinozoisite, epidote, glauconitic } \\
\text { material, chlorite, pyroxene, tourmaline }\end{array}$ \\
\hline ED10284 & $56-03 / 586$ & 5.1 & 4 & $\begin{array}{l}\text { very fine sand } \\
\text { to coarse silt }\end{array}$ & $\begin{array}{l}\text { monocrystalline } \\
\text { quartz }\end{array}$ & $\begin{array}{l}\text { muscovite, biotite, bioclasts, } \\
\text { carbonate minerals, } \\
\text { plagioclase, volcanic rock } \\
\text { fragments }\end{array}$ & $\begin{array}{l}\text { opaque minerals, tourmaline, zoisite/clinozoisite, pyroxene, zircon, amphibole, epidote, } \\
\text { apatite, garnet, polycrystalline quartz, chlorite }\end{array}$ \\
\hline ED10285 & $56-03 / 586$ & 5.8 & 4 & $\begin{array}{l}\text { very fine sand } \\
\text { to coarse silt }\end{array}$ & $\begin{array}{l}\text { monocrystalline } \\
\text { quartz }\end{array}$ & $\begin{array}{l}\text { plagioclase, biotite, } \\
\text { carbonate minerals, } \\
\text { bioclasts, volcanic rock } \\
\text { fragments }\end{array}$ & $\begin{array}{l}\text { amphibole, zoisite/clinozoisite, chlorite, opaque minerals, tourmaline, garnet, apatite, } \\
\text { muscovite, epidote, polycrystalline quartz, zircon, glauconitic material ?rutile, microcline }\end{array}$ \\
\hline ED10286 & $56-03 / 587$ & 0.0 & 4 & $\begin{array}{l}\text { fine to very fine } \\
\text { sand }\end{array}$ & $\begin{array}{l}\text { monocrystalline } \\
\text { quartz }\end{array}$ & $\begin{array}{l}\text { plagioclase, polycrystalline } \\
\text { quartz, altered volcanic rock } \\
\text { fragments }\end{array}$ & $\begin{array}{l}\text { biotite, bioclasts, muscovite, amphibole, opaque minerals, garnet, epidote, zircon, carbonate } \\
\text { minerals, zoisite/clinozoisite, ?rutile, microcline, titanite, metamorphic rock fragments, apatite }\end{array}$ \\
\hline ED10287 & 56-03/587 & 0.5 & 4 & fine sand & $\begin{array}{l}\text { monocrystalline } \\
\text { quartz }\end{array}$ & $\begin{array}{l}\text { plagioclase, polycrystalline } \\
\text { quartz, volcanic rock } \\
\text { fragments }\end{array}$ & $\begin{array}{l}\text { garnet, opaque minerals, chlorite, amphibole, muscovite, biotite, epidote, metamorphic rock } \\
\text { fragments, zoisite/clinozoisite, carbonate minerals, apatite, bioclasts, titanite, ?pyroxene, } \\
\text { glauconitic material, tourmaline, zircon }\end{array}$ \\
\hline
\end{tabular}


Table 2. (continued)

\begin{tabular}{|c|c|c|c|c|c|c|c|}
\hline \multirow[t]{2}{*}{ Sample } & \multirow[t]{2}{*}{ BGS core } & \multirow{2}{*}{$\begin{array}{l}\text { Depth } \\
(\mathrm{m})\end{array}$} & \multirow{2}{*}{$\begin{array}{l}\text { Litho- } \\
\text { zone }\end{array}$} & \multirow[t]{2}{*}{ Lithology } & \multicolumn{3}{|r|}{ Detrital Components } \\
\hline & & & & & Major & Minor & Accessory \\
\hline ED10288 & $56-03 / 587$ & 1.0 & 4 & $\begin{array}{l}\text { medium to fine } \\
\text { sand }\end{array}$ & $\begin{array}{l}\text { monocrystalline } \\
\text { quartz }\end{array}$ & $\begin{array}{l}\text { plagioclase, polycrystalline } \\
\text { quartz, altered volcanic rock } \\
\text { fragments, metamorphic } \\
\text { rock fragments }\end{array}$ & $\begin{array}{l}\text { staurolite, garnet, bioclasts, carbonate minerals, pyroxene, biotite, muscovite, epidote, } \\
\text { amphibole, tourmaline, zircon, chlorite, glauconitic material, very fine-grained basalt, opaque } \\
\text { minerals, apatite, ?rutile }\end{array}$ \\
\hline ED10289 & $56-03 / 587$ & 1.33 & 4 & $\begin{array}{l}\text { medium to fine } \\
\text { sand }\end{array}$ & $\begin{array}{l}\text { monocrystalline } \\
\text { quartz }\end{array}$ & $\begin{array}{l}\text { plagioclase, polycrystalline } \\
\text { quartz, altered volcanic rock } \\
\text { fragments, metamorphic } \\
\text { rock fragments }\end{array}$ & $\begin{array}{l}\text { garnet, opaque minerals, epidote, zoisite/clinozoisite, amphibole, carbonate minerals, } \\
\text { staurolite, biotite, titanite, apatite, chlorite, muscovite, metamafite, zircon, bioclasts, } \\
\text { glauconitic material }\end{array}$ \\
\hline ED10290 & $56-03 / 587$ & 1.48 & 1 & fine sand & $\begin{array}{l}\text { monocrystalline } \\
\text { quartz }\end{array}$ & $\begin{array}{l}\text { plagioclase, polycrystalline } \\
\text { quartz, metamorphic rock } \\
\text { fragments, altered volcanic } \\
\text { rock fragments }\end{array}$ & $\begin{array}{l}\text { microcline, muscovite, epidote, garnet, amphibole, opaque minerals, chlorite, very fine } \\
\text { schistose rock, zircon, pilotaxitic volcanic rock, biotite, pyroxene, bioclasts (rare), tourmaline, } \\
\text { metamafite, zoisite/clinozoisite, hematised volcanic rock, carbonate replaced sandstone (rare) }\end{array}$ \\
\hline ED10291 & $56-03 / 587$ & 1.75 & 1 & $\begin{array}{l}\text { medium to fine } \\
\text { sand }\end{array}$ & $\begin{array}{l}\text { monocrystalline } \\
\text { quartz }\end{array}$ & $\begin{array}{l}\text { plagioclase, polycrystalline } \\
\text { quartz, metamorphic rock } \\
\text { fragments, volcanic rock } \\
\text { fragments }\end{array}$ & $\begin{array}{l}\text { garnet, epidote, amphibole, glauconitic material, myrmekitic intergrowth, zoisite/clinozoisite, } \\
\text { hematised volcanic rock, opaque minerals, apatite, carbonate minerals, biotite, polycrystalline } \\
\text { epidote, muscovite, microcline, very fine-grained pilotaxitic volcanic rock, metamafite, } \\
\text { chloritised biotite schist, bioclasts (rare), sedimentary rock fragments (rare), tourmaline }\end{array}$ \\
\hline ED10292 & $56-03 / 587$ & 2.05 & 1 & $\begin{array}{l}\text { medium to fine } \\
\text { sand }\end{array}$ & $\begin{array}{l}\text { monocrystalline } \\
\text { quartz }\end{array}$ & $\begin{array}{l}\text { plagioclase, polycrystalline } \\
\text { quartz, metamorphic rock } \\
\text { fragments, hematised } \\
\text { volcanic rock fragments }\end{array}$ & $\begin{array}{l}\text { staurolite, polycrystalline epidote, biotite, opaque minerals, tourmaline, carbonate minerals, } \\
\text { titanite, amphibole, garnet, zoisite/clinozoisite, pyroxene, chloritoid, chlorite, epidote, garnet- } \\
\text { biotite schist, fine siltstone/mudstone (rare), metamafite, microcline }\end{array}$ \\
\hline ED10294 & $74 / 15$ & $\begin{array}{l}0-1.5 \\
(4 / 4)^{*}\end{array}$ & 4 & $\begin{array}{l}\text { coarse silt to } \\
\text { very fine sand }\end{array}$ & $\begin{array}{l}\text { monocrystalline } \\
\text { quartz }\end{array}$ & $\begin{array}{l}\text { monocrystalline quartz, } \\
\text { plagioclase }\end{array}$ & $\begin{array}{l}\text { opaque minerals, bioclasts, chlorite, garnet, carbonate minerals, biotite, muscovite, amphibole, } \\
\text { zoisite/clinozoisite, plagioclase, polycrystalline quartz, epidote, tourmaline, glauconitic } \\
\text { material, pyroxene, staurolite }\end{array}$ \\
\hline ED10295 & $74 / 15$ & $\begin{array}{l}1.5-3.5 \\
(1 / 3)^{*}\end{array}$ & 4 & $\begin{array}{l}\text { coarse silt to } \\
\text { very fine sand }\end{array}$ & $\begin{array}{l}\text { monocrystalline } \\
\text { quartz }\end{array}$ & $\begin{array}{l}\text { monocrystalline quartz, } \\
\text { plagioclase, }\end{array}$ & $\begin{array}{l}\text { bioclasts, chlorite, epidote, opaque minerals, carbonate minerals biotite, muscovite, } \\
\text { amphibole, garnet, zircon, plagioclase, zoisite/clinozoisite, rutile, apatite, glauconitic material, } \\
\text { microcline, pyroxene }\end{array}$ \\
\hline ED10296 & $74 / 15$ & $\begin{array}{l}1.5-3.5 \\
(3 / 3)^{*}\end{array}$ & 4 & $\begin{array}{l}\text { coarse silt to } \\
\text { very fine sand }\end{array}$ & $\begin{array}{l}\text { monocrystalline } \\
\text { quartz }\end{array}$ & $\begin{array}{l}\text { monocrystalline quartz, } \\
\text { plagioclase }\end{array}$ & $\begin{array}{l}\text { opaque minerals, carbonate minerals, bioclasts, apatite, epidote, biotite, muscovite, } \\
\text { tourmaline, glauconitic material, zoisite/clinozoisite, garnet, ?pyroxene }\end{array}$ \\
\hline ED10297 & $74 / 15$ & $\begin{array}{l}3.5-5.0 \\
(1 / 3)^{*}\end{array}$ & 3 & coarse silt & $\begin{array}{l}\text { monocrystalline } \\
\text { quartz }\end{array}$ & $\begin{array}{l}\text { monocrystalline quartz, } \\
\text { plagioclase, biotite }\end{array}$ & $\begin{array}{l}\text { opaque minerals, carbonate minerals, muscovite, amphibole, chlorite, zircon, bioclasts, } \\
\text { epidote, garnet, tourmaline, altered volcanic rock fragments (rare) }\end{array}$ \\
\hline ED10298 & $74 / 15$ & $\begin{array}{l}3.5-5.0 \\
(3 / 3)^{*}\end{array}$ & 3 & coarse silt & $\begin{array}{l}\text { monocrystalline } \\
\text { quartz }\end{array}$ & $\begin{array}{l}\text { monocrystalline quartz, } \\
\text { plagioclase, biotite }\end{array}$ & $\begin{array}{l}\text { muscovite, chlorite, epidote, bioclasts, opaque minerals, zircon, carbonate minerals, } \\
\text { zoisite/clinozoisite, amphibole, tourmaline, pyroxene, garnet }\end{array}$ \\
\hline ED10299 & $74 / 15$ & 5.5 & 3 & coarse silt & $\begin{array}{l}\text { monocrystalline } \\
\text { quartz }\end{array}$ & $\begin{array}{l}\text { monocrystalline quartz, } \\
\text { plagioclase, biotite }\end{array}$ & $\begin{array}{l}\text { muscovite, epidote, opaque minerals, amphibole, chlorite, bioclasts, zircon, carbonate } \\
\text { minerals, apatite, garnet, clinozoisite/zoisite }\end{array}$ \\
\hline
\end{tabular}


Table 3. Compositional data (calculated as modal \%) for the sands and silts recovered in BGS vibrocores 56-03/586, 56-03/587 and borehole 74/15. Qm - monocrystalline quartz; Qp - polycrystalline quartz; Pl - plagioclase; Ksp - K-feldspar; Lv - volcanic lithic clasts; Ls - sedimentary lithic clasts; Lm- metamorphic lithic clasts; L total - total lithic component; Bio - biotite; Mu - muscovite; Chl - chlorite; Gt - garnet; St - staurolite; Op - opaque minerals; Hb - amphibole; Ep - epidote; Ap - apatite; Px -

pyroxene; Ctd - chloritoid; CC - detrital carbonate minerals (both finely crystalline and micritic); bioclasts - bioclastic debris (e.g. foraminifera, ostracods). N, number of grains point counted; * samples ED10278 and ED10295 too few grains to point count.

\begin{tabular}{|c|c|c|c|c|c|c|c|c|c|c|c|c|c|c|c|c|c|c|c|c|c|c|c|c|}
\hline \multirow[t]{2}{*}{ Sample* } & \multirow[t]{2}{*}{ BGS core } & \multirow{2}{*}{$\begin{array}{l}\text { Litho- } \\
\text { zone }\end{array}$} & \multirow[t]{2}{*}{$\mathrm{N}$} & \multicolumn{21}{|c|}{ calculated as percentage } \\
\hline & & & & $\mathrm{Qm}$ & Qp & $\mathrm{Pl}$ & Ksp & $\mathrm{Lv}$ & Ls & Lm & L total & Bio & $\mathrm{Mu}$ & Chl & Gt & St & Op & $\mathrm{Hb}$ & Ep & Ap & Px & Ctd & CC & $\begin{array}{l}\text { Bio- } \\
\text { clasts }\end{array}$ \\
\hline ED10279 & $56-03 / 586$ & 4 & 612 & 60.45 & 3.75 & 9.80 & 0.16 & 3.43 & 0.16 & 0.81 & 8.16 & 3.10 & 3.59 & 1.96 & 0.16 & 0 & 1.96 & 3.26 & 1.47 & 0.32 & 0.16 & 0 & 4.73 & 0.65 \\
\hline ED10280 & $56-03 / 586$ & 4 & 525 & 56.95 & 4.38 & 11.42 & 0.95 & 4.76 & 0.19 & 0.76 & 10.09 & 3.04 & 3.42 & 3.42 & 0.19 & 0 & 2.09 & 2.09 & 0.19 & 0.19 & 0 & 0 & 3.80 & 1.90 \\
\hline ED10281 & $56-03 / 586$ & 4 & 608 & 57.73 & 4.76 & 8.22 & 0.82 & 5.09 & 2.79 & 0.32 & 12.99 & 1.64 & 2.63 & 2.13 & 0 & 0 & 2.63 & 1.97 & 0.49 & 0 & 0 & 0 & 4.76 & 3.94 \\
\hline ED10282 & $56-03 / 586$ & 4 & 637 & 53.21 & 4.86 & 11.30 & 0.94 & 3.92 & 0.62 & 0.31 & 9.73 & 4.86 & 2.66 & 2.66 & 0.31 & 0 & 0.78 & 2.51 & 1.41 & 0.15 & 0 & 0 & 7.22 & 2.19 \\
\hline ED10283 & 56-03/586 & 4 & 672 & 63.09 & 4.61 & 13.98 & 0.59 & 2.38 & 0.14 & 0.44 & 7.58 & 0.89 & 2.23 & 1.63 & 0 & 0 & 0.59 & 1.93 & 1.19 & 0.44 & 0 & 0 & 4.91 & 0.74 \\
\hline ED10284 & $56-03 / 586$ & 4 & 627 & 60.28 & 2.39 & 7.17 & 0.47 & 3.50 & 0.31 & 0.31 & 6.53 & 4.62 & 3.82 & 3.18 & 0.15 & 0 & 1.43 & 2.71 & 1.11 & 0.31 & 0 & 0 & 6.06 & 1.75 \\
\hline ED10285 & $56-03 / 586$ & 4 & 578 & 56.40 & 5.19 & 14.01 & 1.03 & 2.76 & 0.51 & 1.21 & 9.68 & 2.59 & 2.24 & 1.90 & 0.34 & 0 & 0.86 & 1.73 & 0.86 & 0.34 & 0 & 0 & 6.40 & 1.21 \\
\hline ED10286 & $56-03 / 587$ & 4 & 619 & 58.48 & 2.90 & 10.17 & 0.16 & 8.88 & 0 & 0.48 & 12.27 & 2.10 & 4.36 & 2.26 & 0 & 0 & 1.45 & 2.26 & 0.96 & 0.16 & 0 & 0 & 3.87 & 1.45 \\
\hline ED10287 & $56-03 / 587$ & 4 & 695 & 56.69 & 3.74 & 12.51 & 0.57 & 4.60 & 0 & 1.58 & 9.92 & 1.72 & 2.87 & 1.87 & 0.28 & 0 & 2.15 & 2.30 & 2.30 & 0.43 & 0 & 0 & 4.46 & 1.87 \\
\hline ED10288 & 56-03/587 & 4 & 674 & 54.15 & 4.89 & 10.97 & 0.29 & 8.60 & 0 & 2.37 & 15.87 & 1.92 & 2.37 & 1.33 & 1.18 & 0.14 & 2.07 & 1.78 & 0.89 & 0 & 0 & 0 & 3.11 & 3.85 \\
\hline ED10289 & 56-03/587 & 4 & 703 & 54.76 & 5.54 & 10.52 & 0.28 & 9.38 & 0 & 3.84 & 18.77 & 0.99 & 1.84 & 0.85 & 1.56 & 0 & 1.99 & 1.28 & 1.70 & 0.14 & 0 & 0 & 3.55 & 1.70 \\
\hline ED10290 & $56-03 / 587$ & 1 & 739 & 53.58 & 6.76 & 10.69 & 1.48 & 12.31 & 0.67 & 4.19 & 23.95 & 0.81 & 1.48 & 0.67 & 0.54 & 0 & 0.40 & 1.48 & 1.08 & 0 & 0.13 & 0 & 3.65 & 0 \\
\hline ED10291 & $56-03 / 587$ & 1 & 700 & 51.85 & 9.71 & 11.14 & 0.42 & 10 & 0.42 & 7.42 & 27.57 & 0.85 & 0.42 & 0.57 & 1.42 & 0 & 1 & 1 & 0.28 & 0 & 0.14 & 0 & 2.71 & 0.57 \\
\hline ED10292 & $56-03 / 587$ & 1 & 727 & 46.76 & 10.45 & 9.21 & 1.65 & 11.96 & 0.68 & 11.41 & 34.52 & 0.27 & 0.68 & 0 & 0.41 & 0 & 1.37 & 1.65 & 0.41 & 0 & 0 & 0.13 & 2.88 & 0 \\
\hline ED10293 & $74 / 15$ & 4 & 514 & 62.45 & 3.30 & 14.00 & 0.58 & 5.83 & 0 & 1.94 & 11.08 & 1.55 & 1.36 & 1.94 & 0.38 & 0 & 0.58 & 1.75 & 0.38 & 0 & 0 & 0 & 3.30 & 0.58 \\
\hline ED10294 & $74 / 15$ & 4 & 543 & 60.58 & 4.78 & 13.25 & 0 & 5.15 & 0.36 & 0.73 & 11.04 & 2.39 & 2.57 & 1.28 & 0 & 0 & 1.28 & 1.28 & 0.55 & 0 & 0 & 0 & 5.15 & 0.36 \\
\hline ED10296 & $74 / 15$ & 4 & 654 & 62.23 & 4.58 & 13.14 & 0.61 & 5.04 & 0.15 & 0.61 & 10.39 & 1.52 & 1.22 & 1.37 & 0.30 & 0 & 0.76 & 1.83 & 1.37 & 0.45 & 0 & 0 & 3.66 & 0.91 \\
\hline ED10297 & $74 / 15$ & 3 & 517 & 62.28 & 3.67 & 14.89 & 0 & 3.48 & 0 & 0 & 7.15 & 2.32 & 2.51 & 1.93 & 0.38 & 0 & 0.77 & 1.74 & 0.58 & 0.19 & 0 & 0 & 4.06 & 1.16 \\
\hline ED10298 & $74 / 15$ & 3 & 323 & 66.87 & 0.92 & 5.88 & 0 & 1.85 & 0 & 0 & 2.78 & 5.26 & 4.02 & 2.78 & 0 & 0 & 0.92 & 2.47 & 2.16 & 0.30 & 0 & 0 & 5.26 & 1.23 \\
\hline ED10299 & $74 / 15$ & 3 & 310 & 65.48 & 1.29 & 10.32 & 0 & 1.93 & 0 & 0.32 & 3.54 & 3.87 & 5.16 & 4.19 & 0.64 & 0 & 1.29 & 0.64 & 0.96 & 0 & 0 & 0 & 3.54 & 0.32 \\
\hline
\end{tabular}


Table 4. Summary of key aspects of petrographic and compositional data for lithozones 1, 3 and 4.

\begin{tabular}{|c|c|c|c|c|c|c|}
\hline Lithozone & $\begin{array}{l}\text { Main components } \\
(\text { modal \%) }\end{array}$ & Nature of quartz & Lithic fragments & $\begin{array}{l}\text { Main accessory } \\
\text { minerals }\end{array}$ & Grain shape & Carbonate fraction \\
\hline 1 & $\begin{array}{l}\text { Quartz }(55-65) \\
\text { Lithics }(24-35) \\
\text { Plagioclase }(\leq 10)\end{array}$ & $\begin{array}{l}\text { Mostly monocrystalline; } \\
\text { polycrystalline up to } 10 \% \text {. } \\
\text { Former increases up core, } \\
\text { whereas latter shows } \\
\text { complementary decrease }\end{array}$ & $\begin{array}{l}\text { Equal mix of } \\
\text { volcanic and } \\
\text { metamorphic }\end{array}$ & $\begin{array}{l}\text { Muscovite, garnet } \\
\text { and hornblende, }\end{array}$ & $\begin{array}{l}\text { Angular to } \\
\text { subrounded; variable } \\
\text { sphericity }\end{array}$ & $\begin{array}{l}\text { Bioclastic material } \\
\text { very rare; detrital } \\
\text { carbonate ranges } \\
\text { from } 2.71-3.65 \%\end{array}$ \\
\hline 3 & $\begin{array}{l}\text { Quartz }(\leq 65) \\
\text { Plagioclase }(\leq 14) \\
\text { Mica }(\leq 9) \\
\text { Lithics }(\leq 7)\end{array}$ & $\begin{array}{l}\text { Mostly monocrystalline; } \\
\text { polycrystalline } \leq 3 \%\end{array}$ & Mostly volcanic & $\begin{array}{l}\text { Chlorite, hornblende } \\
\text { and epidote }\end{array}$ & $\begin{array}{l}\text { Angular; variable } \\
\text { sphericity }\end{array}$ & $\begin{array}{l}\text { Bioclastic material } \\
\text { low; detrital } \\
\text { carbonate ranges } \\
\text { from } 3.54-5.26 \%\end{array}$ \\
\hline $\begin{array}{l}4 \\
\text { (clinofrom } \\
\text { facies) }\end{array}$ & $\begin{array}{l}\text { Quartz }(60-68) \\
\text { Plagioclase }(7-14) \\
\text { Lithics }(7-13) \\
\text { Mica }(2.5-8.5)\end{array}$ & $\begin{array}{l}\text { Mostly monocrystalline, } \\
\text { and increases to top of } \\
\text { L4; polycrystalline } \leq 5 \%\end{array}$ & Mostly volcanic & $\begin{array}{l}\text { Chlorite, hornblende } \\
\text { and epidote }\end{array}$ & $\begin{array}{l}\text { Angular to } \\
\text { subrounded; variable } \\
\text { sphericity }\end{array}$ & $\begin{array}{l}\text { Bioclastic material } \\
\text { common; detrital } \\
\text { carbonate ranges } \\
\text { from } 3.8-7.2 \%\end{array}$ \\
\hline $\begin{array}{l}4 \\
\text { (topset } \\
\text { facies) }\end{array}$ & $\begin{array}{l}\text { Quartz }(\leq 60) \\
\text { Lithics }(9-18) \\
\text { Plagioclase }(10-12) \\
\text { Mica }(2.65-6.5)\end{array}$ & $\begin{array}{l}\text { Mostly monocrystalline; } \\
\text { polycrystalline } \leq 5.5 \% \text {. } \\
\text { Former increases up core, } \\
\text { whereas latter shows } \\
\text { complementary decrease }\end{array}$ & $\begin{array}{l}\text { Mostly volcanic, but } \\
\text { metamorphic locally } \\
\text { up to } 40 \% \text { at base of } \\
\text { section }\end{array}$ & $\begin{array}{l}\text { Chlorite, hornblende, } \\
\text { epidote and garnet }\end{array}$ & $\begin{array}{l}\text { Angular to } \\
\text { subangular, variable } \\
\text { sphericity }\end{array}$ & $\begin{array}{l}\text { Bioclastic material } \\
\text { common; detrital } \\
\text { carbonate ranges } \\
\text { from } 3-4.5 \%\end{array}$ \\
\hline
\end{tabular}


Table 5. Distribution of foraminifera in BGS vibrocores 56-03/586, 56-03/587 and borehole 74/15.

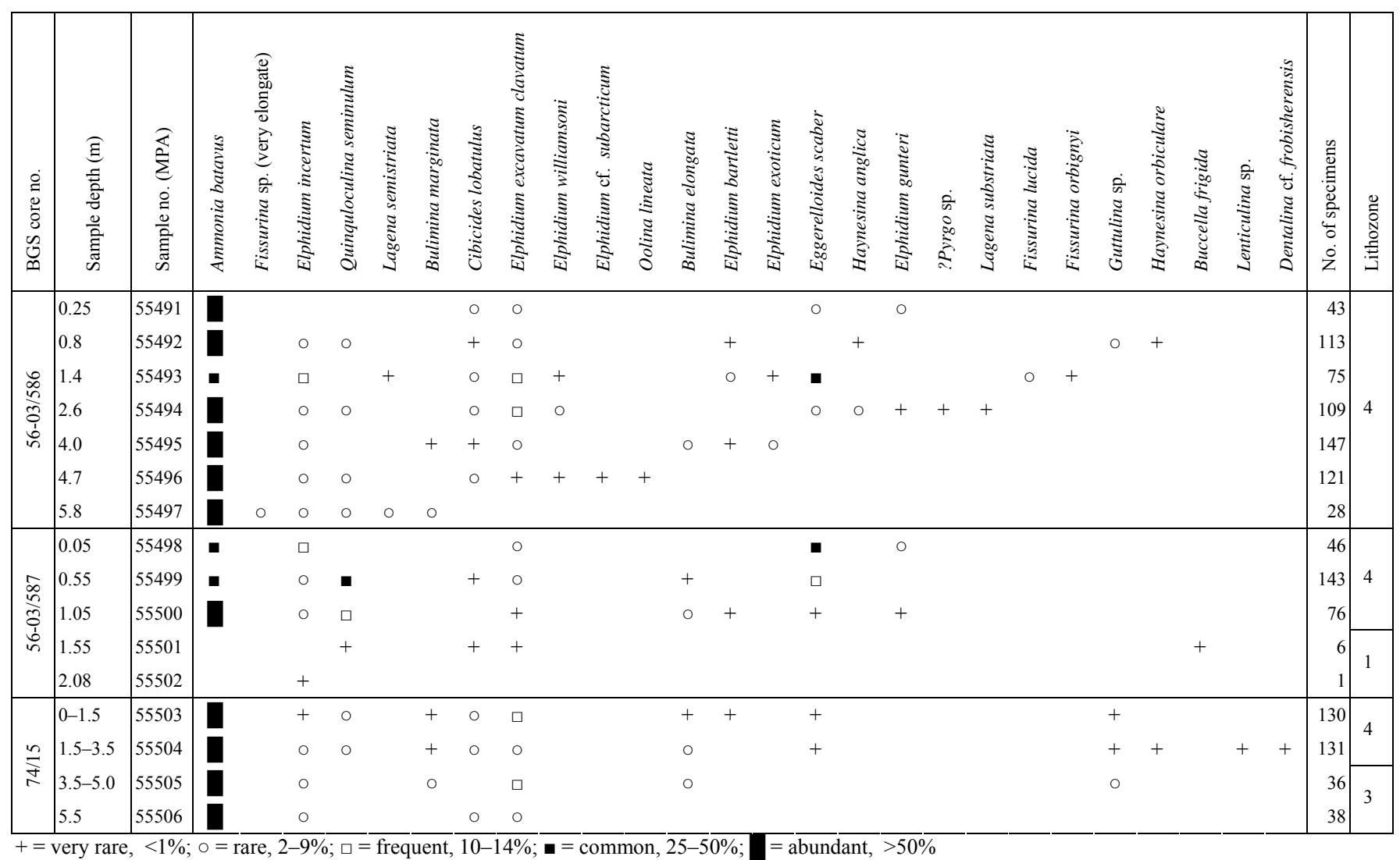


Table 6. Distribution of ostracods in BGS vibrocores 56-03/586, 56-03/587 and borehole 74/15.

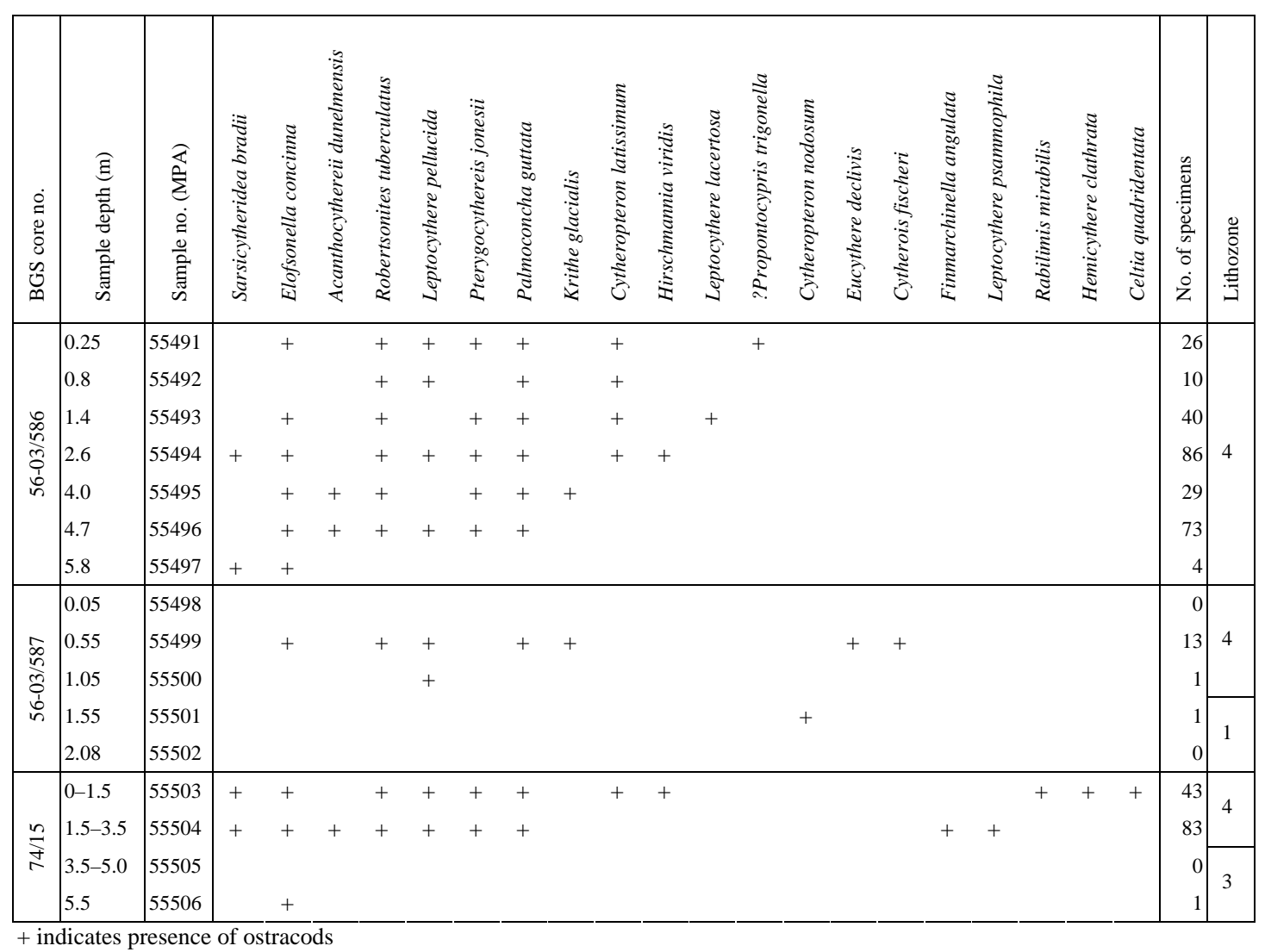


Table 7. AMS ${ }^{14} \mathrm{C}$ dates

\begin{tabular}{|c|c|c|c|c|c|c|}
\hline $\begin{array}{l}\text { Laboratory } \\
\text { code }\end{array}$ & Core & $\begin{array}{l}\text { Depth in } \\
\text { core }(m)\end{array}$ & Dated material & $\begin{array}{l}\text { Conventional } \\
\text { age }\left({ }^{14} \mathrm{C} \text { yr } \mathrm{BP}\right)\end{array}$ & $\begin{array}{l}\text { Adjusted }{ }^{1} \\
\text { age }\left({ }^{14} \mathrm{C} \text { yr BP }\right)\end{array}$ & $\begin{array}{l}\text { Calibrated age }^{2} \\
\text { (cal. yr) }\end{array}$ \\
\hline SUERC-11213 & $56-03 / 587$ & 1.3 & Arctica islandica & $1782 \pm 35$ & $1377 \pm 53$ & $1294 \pm 31$ \\
\hline SUERC-14786 & $56-03 / 586$ & $2.27-2.4$ & Ammonia batavus & $2624 \pm 37$ & $2219 \pm 54$ & $2237 \pm 80$ \\
\hline SUERC-13619 & $56-03 / 586$ & $2.55-2.65$ & Ammonia batavus & $2629 \pm 37$ & $2224 \pm 54$ & $2243 \pm 78$ \\
\hline SUERC-13618 & $74 / 15$ & $3.5-5.0$ & Ammonia batavus & $5349 \pm 35$ & $4944 \pm 53$ & $5665 \pm 56$ \\
\hline SUERC-13620 & $74 / 15$ & 5.5 & Ammonia batavus & $5364 \pm 36$ & $4959 \pm 54$ & $5681 \pm 62$ \\
\hline SUERC-11214 & $56-03 / 587$ & 2.0 & Macoma calcarea & $10948 \pm 38$ & $10543 \pm 55$ & $12500 \pm 72$ \\
\hline
\end{tabular}

${ }^{1}$ Marine reservoir correction $405 \pm 40$ (Harkness 1983)

${ }^{2}$ Fairbanks0107 calibration curve (Fairbanks et al. 2005), based on adjusted age. 
Table 8. Summary and interpretation of lithozones 1, 3 and 4. Interpretation of lithozone 2 based on seismic association with L3 and L4 (see text for details).

\begin{tabular}{|c|c|c|c|c|c|c|}
\hline Lithozone & Clinoform Profile & Lithology & Provenance & $\begin{array}{l}\text { Microfaunal } \\
\text { Assemblage }\end{array}$ & Interpretation & Age \\
\hline 4 & $\begin{array}{l}\text { Sigmoid-oblique; dip } \\
0.25-0.5^{\circ}\end{array}$ & $\begin{array}{l}\text { Medium sand to } \\
\text { coarse silt, with } \\
\text { basal shell hash }\end{array}$ & $\begin{array}{l}\text { Mainly offshore, } \\
\text { reworking }\end{array}$ & $\begin{array}{l}\text { Lusitanian to low } \\
\text { Boreal }\end{array}$ & $\begin{array}{l}\text { Highstand, } \\
\text { shoreface wedge }\end{array}$ & Late Holocene \\
\hline 3 & $\begin{array}{l}\text { Mainly reflection free, } \\
\text { but weak oblique- } \\
\text { tangential; dip } 0.25- \\
0.5^{\circ}\end{array}$ & $\begin{array}{l}\text { Very fine-grained } \\
\text { sand to coarse silt }\end{array}$ & $\begin{array}{l}\text { Mainly offshore, } \\
\text { reworking }\end{array}$ & $\begin{array}{l}\text { Lusitanian to low } \\
\text { Boreal }\end{array}$ & $\begin{array}{l}\text { Highstand, } \\
\text { shoreface wedge }\end{array}$ & Mid-Holocene \\
\hline 2 & $\begin{array}{l}\text { Sigmoid-oblique } \\
\text { tangential; dip } 0.25 \text { - } \\
0.5^{\circ}\end{array}$ & No data & No data & No data & $\begin{array}{l}\text { Highstand, } \\
\text { shoreface wedge? }\end{array}$ & Mid-Holocene? \\
\hline 1 & $\begin{array}{l}\text { Oblique-parallel; dip } \\
1.0-1.2^{\circ}\end{array}$ & $\begin{array}{l}\text { Medium sand to } \\
\text { coarse silt }\end{array}$ & $\begin{array}{l}\text { Onshore, NE } \\
\text { Scotland volcanic } \\
\text { \& metamorphic } \\
\text { terranes }\end{array}$ & High Arctic & $\begin{array}{l}\text { Lowstand, delta } \\
\text { wedge }\end{array}$ & $\begin{array}{l}\text { Younger Dryas } \\
\text { Stadial }\end{array}$ \\
\hline
\end{tabular}

